(i)

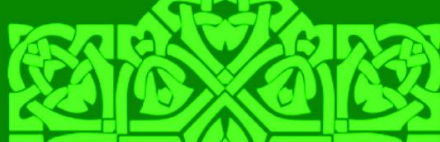
tह

Muhammad Yusuf, Baharuddin, Mardan The Quranic Hermeneutics Approach to Gender Equality in Amina Wadud Muhsin's View

A. Zamakhsyari Baharuddin التظاهر بالشعار ات القومية في شعيرة الحج و العمرة

Andi Muhammad Ridwan, Baso Pallawagau Falsafah Al-Wujudiyyah Al-Sufiyyah: Asluha Al-Dini wa Manqif Al-Ulama Minha

Muhammad Widus Sempo, Norita Binti Md Norwawi, Hasyim Haddade, Yousuf Mahbubul Islam, Noorhayati Binti Hasyim Unbelievers' Mental Model and Behavioural Disorders Based on Their Queries in The Al-Baqarah Chapter

Sri Sunantri, Achmad Abubakar, Kamaluddin Abu Nawas, Firdaus Methodology of Interpretation of Muhammad Amin Al-Syinqiti

Amirullah, Andi Achruh AB. Pasinringi, Rahmawansyah Sahib The Transformation of The Muamalah Fiqh Akad at Saga Abepura-Papua Mall During The Covid 19 Pandemic

Irwan Misbach Siri'Na Pacce Culture in Retailer Based on Islamic Perspective Business Ethics

Abd. Rahman R Family Resilience in Islamic Perspective (A Case Study of Parent and Child Interaction Behavior in The District of Somba Opu Gowa)

Vol. 20 No. $2 / 2020$ 


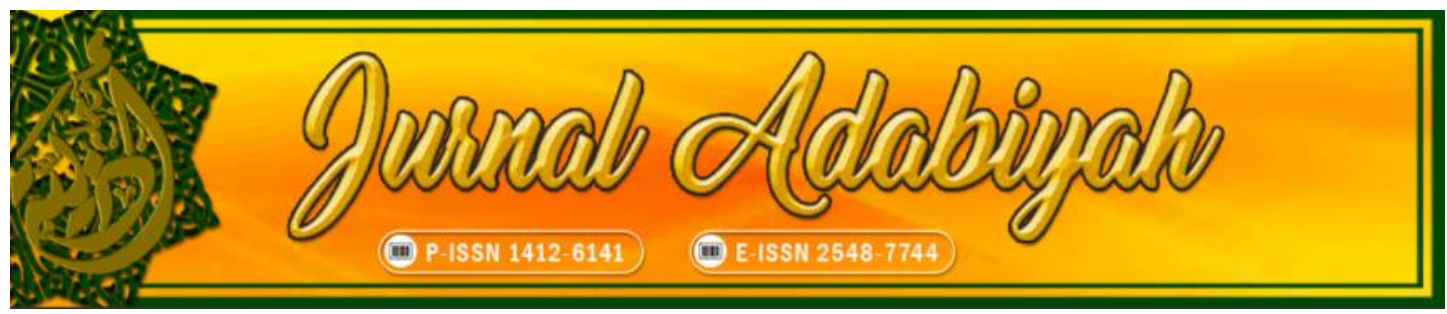

Theme: Islamic Studies

VOLUME 20 NO. 2 DECEMBER 2020

\section{EDITOR-IN-CHIEF}

Barsihannor, Alauddin State Islamic University, Indonesia

\section{INTERNATIONAL EDITORIAL BOARD}

Nuri Emmiyati, Alauddin State Islamic University, Indonesia

Minako Sakai, Australian National University (ANU), Australia

Abd Rauf Muhammad Amin, Fakulti Syariah Kupu SB Brunei Darussalam, Brunei Darussalam

Muhammad Widus Sempo, Universiti Sains Islam Malaysia, Malaysia

Salih Yousif Sharaf Mohamed, Al-Gazera University, Sudan

Aishah Waenaha Waemamah, Academy of Islamic and Arabic Studies Princess of Naradhiwas University - Thailand, Thailand

\section{EXECUTIVE EDITOR}

Umar Thamrin, Alauddin State Islamic University, Indonesia

\section{MANAGING EDITOR}

Nasrum, Alauddin State Islamic University, Indonesia

\section{EDITORS}

Rosmah Tami, Alauddin State Islamic University, Indonesia Haniah Haniah, Alauddin State Islamic University, Indonesia Zaenal Abidin, Alauddin State Islamic University, Indonesia

Awaluddin Syamsu, Universitas Muslim Indonesia

Ahmadi Usman, UIN Syarif Hidayatullah Jakarta, Indonesia

Baso Pallawagau, Alauddin State Islamic University, Indonesia

Muhammad Azwar, UIN Syarif Hidayatullah Jakarta, Indonesia

Muh. Saleh Syamsuri, Alauddin State Islamic University, Indonesia

Andi Satrianingsih, Muhammadiyah University, Indonesia

Syahruni - Junaid, Alauddin State Islamic University, Indonesia

Rabiatul Adawiah, Majene Islamic State College, West Sulawesi, Indonesia, Indonesia

Chusnul Chatimah Asmad, Alauddin State Islamic University, Indonesia

Nur Arifin, Alauddin State Islamic University, Indonesia

\section{IT SUPPORT}

Taufiq Mathar, Alauddin State Islamic University, Indonesia

\section{LANGUAGE ADVISOR}

Kustiwan Syarief, UIN Syarif Hidayatullah Jakarta, Indonesia Muh. Saleh Syamsuri, Alauddin State Islamic University, Indonesia

\section{COVER DESIGNER}

Nur Arifin 


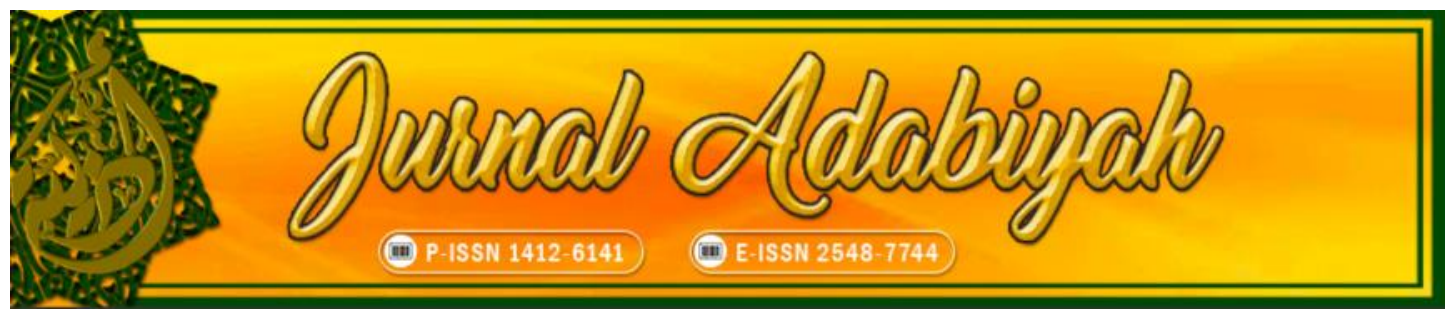

\section{Jurnal Adabiyah:}

This journal receives a national accreditation from Ministry of Research, Technology, and Higher Education Republic of Indonesia, Nomor 10/E/KPT/2019 on April 4, 2019 with the SINTA score: S2.

The Journal has been published by the Faculty of Adab and Humanity of Alauddin State Islamic University, Makassar, since 1997 and has been online since 2016 with the main themes on Humanities and Islamic Studies with the emphasis on interdisciplinary and intertextuality approach.

This journal are published twice a year, on June and December. The themes related to Islamic Studies are textual studies, scriptural traditions, Islamic law, and theology; and those related to Humanities are language, literature, history, and culture.

The journal of Humanities and Islamic Studies will provide the online collection of articles from 1997 up to now. The most updated information can be found on the website. 


\section{Table of Contents}

Muhammad Yusuf, Baharuddin, Mardan

214-237

The Quranic Hermeneutics Approach to Gender Equality in Amina Wadud Muhsin's View

A. Zamakhsyari Baharuddin

التظاهربالشعارات القومية في شعيرة الحج والعمبرة

261-285

Andi Muhammad Ridwan, Baso Pallawagau

Falsafah Al-Wujudiyyah Al-Sufiyyah: Asluha Al-Dini wa Mauqif AlUlama Minha

Muhammad Widus Sempo, Norita Binti Md Norwawi, Hasyim Haddade, Yousuf Mahbubul Islam, Noorhayati Binti Hasyim ................... 286-299 Queries in The Al-Baqarah Chapter

Sri Sunantri, Achmad Abubakar, Kamaluddin Abu Nawas, Firdaus. 300-319 Methodology of Interpretation of Muhammad Amīn Al-Syinqiti

Amirullah, Andi Achruh AB. Pasinringi, Rahmawansyah Sahib

The Transformation of The Muamalah Fiqh Akad at Saga Abepura-Papua Mall During The Covid 19 Pandemic

Irwan Misbach

Siri' Na Pacce Culture in Retailer Based on Islamic Perspective Business Ethics

Abd Rahman R

Family Resilience in Islamic Perspective (A Case Study of Parent and Child Interaction Behavior in The District of Somba Opu Gowa) 


\title{
التظاهر بالشعارات القومية في شعيرة الحج والعمرة
}

\author{
A. Zamakhsyari Baharuddin \\ Sekolah Tinggi Agama Islam Negeri (STAIN) Majene \\ Email: ansamad90@gmail.com
}

\begin{abstract}
الملخص
يهدف هذا البحث إلى التعرف على مدى شرعية التظاهر بالشعارات القومية

والطائفية في شعيرة الحج والعمرة، فالبحث ما هو إلا محاولة لإبراز معالم

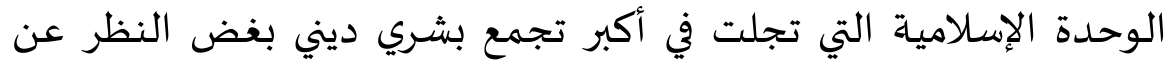

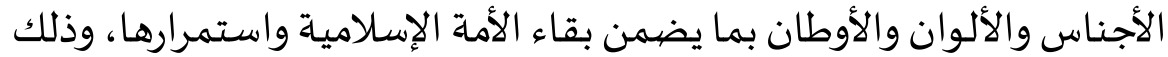

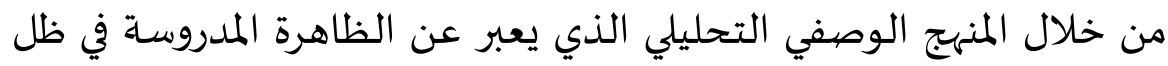

الظروف التي تتواجد فيها تعبيرا كميا وكيفيا بل يتعدى ذلك إلى تحليلها

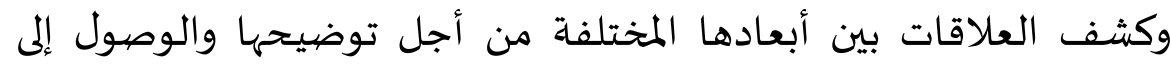

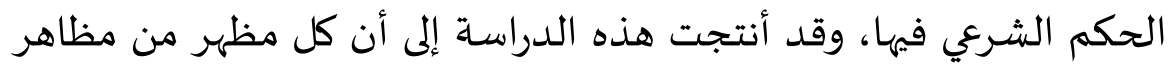

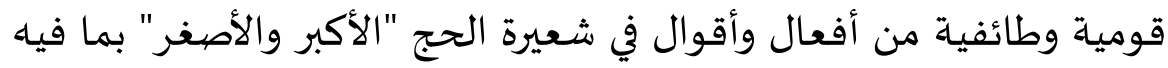

تفريق وتفكيك لوحدة المسلمين ليس مشروعا بل رفضيه الإسلام، وأن الأخوة

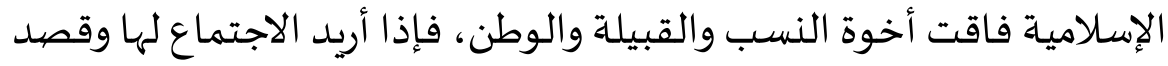

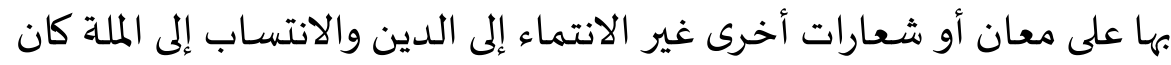

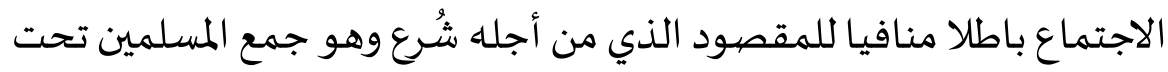

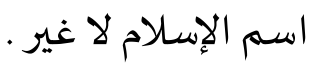

كلمات المفاتيح: التظاهر - الشعارات عيرات - القومية - الحج - العمرة
\end{abstract}

\begin{abstract}
This study aims to determine the legitimacy of the demonstration of the sectarian (national) slogan in the Hajj and Umrah rituals. This research is an attempt to highlight the milestones of Islamic unity that are manifested in the largest religious congregation regardless of race, color, and country so as to ensure the survival of ummah, through descriptive and analytical approaches related to the phenomena studied based on its circumstances. The study found that every national and sectarian aspect of akctions in the Hajj and Umrah rituals, including the separation and disintegration of the unity of the Muslims, is not legitimate but rejected by Islam, and that Islamic brotherhood transcends the brotherhood of lineage, ethnicity and homeland, then if the meeting is intended for a meaning or slogan other
\end{abstract}


than religion, then the meeting is invalid and contrary to the stated purpose, namely gathering Muslims in the name of Islam only.

Keywords: Demonstratoin; Slogans; Nation; Hajj; Umrah

\begin{abstract}
Abstrak
Penelitian ini bertujuan untuk mengetahui legitimasi demonstrasi slogan sektarian (nasional) dalam ritual Haji dan Umrah. Penelitian ini merupakan upaya untuk menyoroti tonggak-tonggak persatuan Islam yang terwujud dalam pertemuan umat beragama terbesar tanpa memandang ras, warna kulit, dan negara sehingga menjamin kelangsungan hidup dan keberlangsungan umat, melalui pendekatan deskriptif dan analitis terkait fenomena yang dikaji berdasarkan keadaannya, studi ini menemukan bahwa setiap aspek nasionalisme dan sektarianisme dalam ritual haji dan umrah yang dapat memecahkan persatuan ummat tidak dibenarkan, dan bahwasanya persaudaraan Islam itu melampaui persaudaraan garis keturunan, suku, dan tanah air, jadi jika pertemuan itu dimaksudkan pada makna atau slogan selain agama maka pertemuan itu tidak sah dan bertentangan dengan tujuan yang ditetapkan, yaitu pertemuan umat Islam dengan nama Islam semata.
\end{abstract}

Keywords: Demonstrasi; Slogans; Nasional; Haji; Umrah

$$
\begin{aligned}
& \text { إن قضيـة الوطن ليست قضية أفراد، ولا هي قضية فئة، ولا هي قضية } \\
& \text { جماعاة، ولا هي قضية نيابة ولكنها في المقام الأول قضية وطن قام على المحبة لا } \\
& \text { الكراهية، وتأسس على الاتفاق لا الافتراق، وما أصاب إندونيسيا في الآونة الأخيرة من } \\
& \text { تفكك وانقسام حرّك شعبها من أتباع جمعية حركة شباب نهضية العلماء "أنصار" إلى } \\
& \text { أخذ موقف أكثر حزما وهو رفح هتافات تنادي بالوحدة القومياة "يا للوطن" وسط } \\
& \text { المسعى في مكة المكرمة أثناء أداء مناسك العمرة، ولم يمض إلا أوقات قليلة ليصاب } \\
& \text { بعدد من الاعتراضيات والانتقادات من قبل أطراف الجماهير في إندونيسيا بصفة عامة } \\
& \text { وبالخصيوص من قبل أهل العلم. } \\
& \text { وعندما طلب التوضيح لبيان السبب الذي من أجله قاموا بالهتافات قال } \\
& \text { الرئيس العام لجمعيـة أنصار يعقوت خليل "إن هذه الهتافات ما هي إلا عفويـة تنبع من }
\end{aligned}
$$


ممارسات متكررة في تنشيد وهتاف يا للوطن"، 1 لكن الأرض الواقع تشهد أن هذا

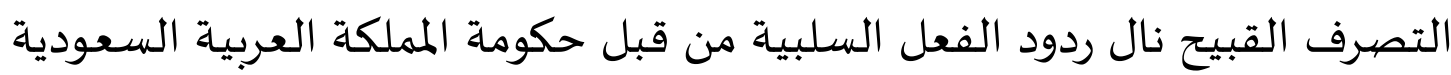
بحيث أشار السفير السعودي لدى إندونيسيا إلى أن استخدام أي شعارات سياسية

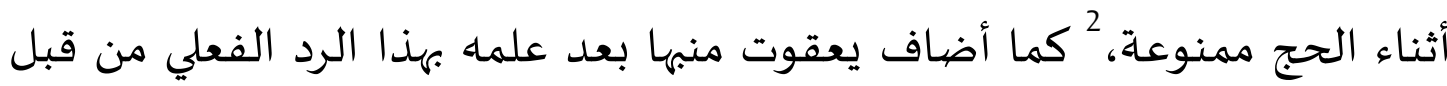

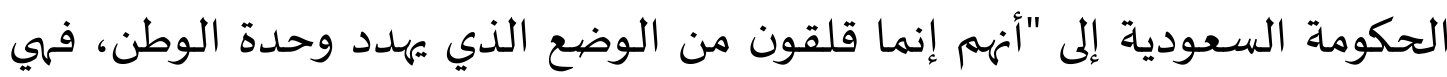
مجرد عفوية تنبع من حبهم للوطن وليست لأغراض سياسياة". 3

وإزاء هذا كله فقد دار جدل فقهي وفكري حول هذا التصرف بئ ولين العلماء

والمفكرين في ساحة الإعلام الإندونيسي، بل وقد اتخذ هذا الجدل الشنيع أبعادا

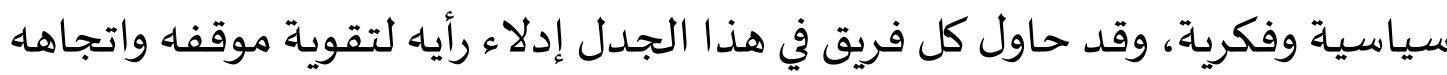

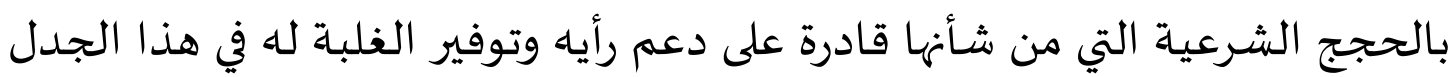
الشنيع.

ومما يجدر الإشارة إليه أن هذا التصرف إذا لم يتم بيانه بصورة أوضح،

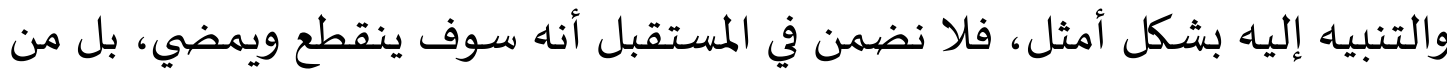

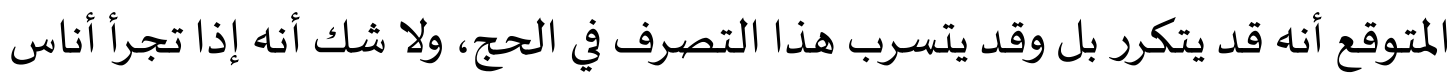

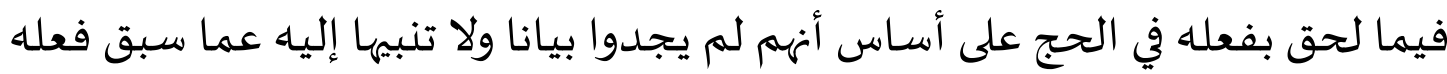

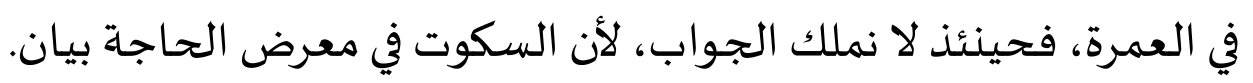

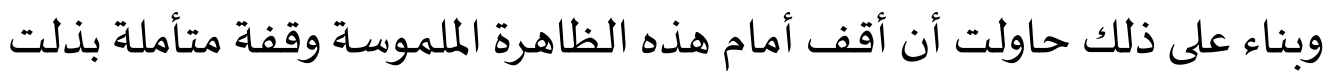
فيها خالص جهدي وقصارى معرفتي، وسعيت بكل ما أوتيت من قوة وعلم - على قلة

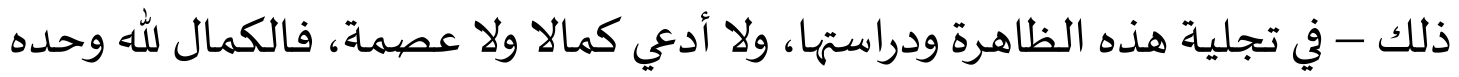
والعصيمة لأنبيائه صلوات الله عليهم وسلامهاه. هدها

1 "Penjelasan Banser Soal Yaa Lal Wathan di Mekkah: Murni Spontanitas," MusliModerat, 2018, http://www.muslimoderat.net/2018/02/penjelasan-banser-soal-yaa-lal-wathan.html.

2 Pirman, "Tegas! Begini Cara Arab Saudi 'Semprot' Penyanyi Ya Lal Wathon Saat Sa'i," Tarbawiyah Net, 2018, https://www.tarbawia.net/2018/02/tegas-begini-cara-arab-saudi-semprot.html.

3 “Penjelasan Banser Soal Yaa Lal Wathan di Mekkah: Murni Spontanitas." 
وأنباه إلى أن محور هذا البحث يرتكز حول التعرف على حكم التظاهر

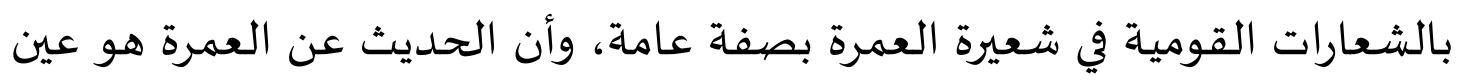

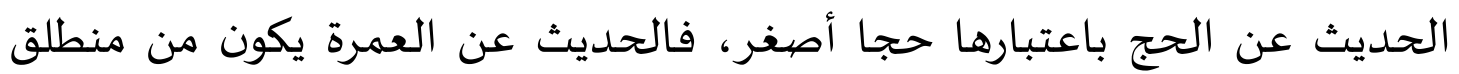

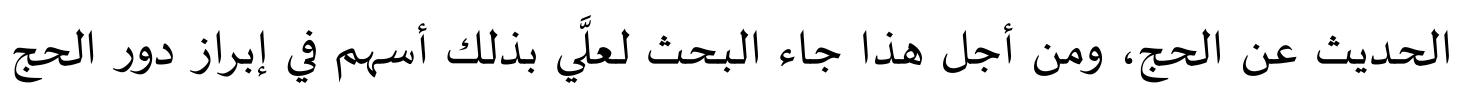
والعمرة في تقوية وحدة الأماة وبقائها.

\section{ب. منهج البحث}

بناء على موضوع هذه الدراسة وأهدافها، اتبعت المنهج الوصفي التحليلي، حيث تهدف هذه الدراسة إلى وصف الظاهرة المدروسة في ظل الظروف التي تتواجد فيها، ثم يتم تحليل البياتات التي تم جمعها عن طريق المنهج الوصيفي حتى يمكن إعطاء

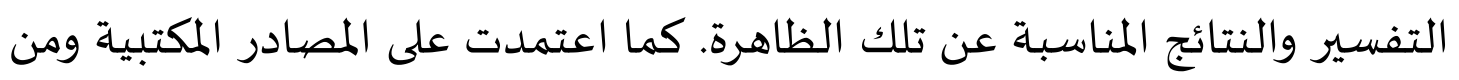

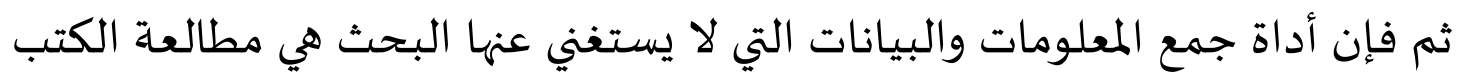

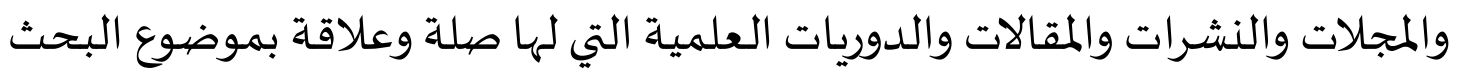

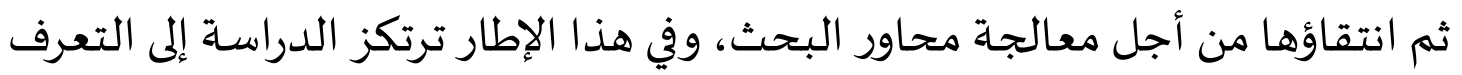
على الوعي الشرعي بحكم التظاهر بالشعارات القومية أثناء الحج والعمرة.

ج. النتائج والمناقشات

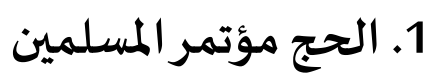

لا يخفى على العالمين أن الحج هو أكبر تجمع بشري ديني منظم في العالم على

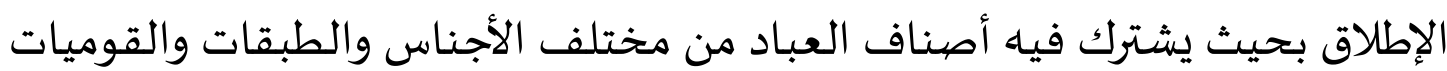
على موعد واحد وفي مكان واحد، يجمعههم هتاف واحد وهو "لبيك اللههم لبيك، لبيك

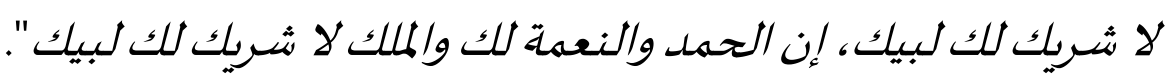


ومن العجب أن هذه الشعيرة جعلت الأشكال والألوان والأوطان واللغات والمناصب والجاه تذوب في وحدة العقيدة، وتنصهر في بوتقة الإسلام الذي لا يفرق بين

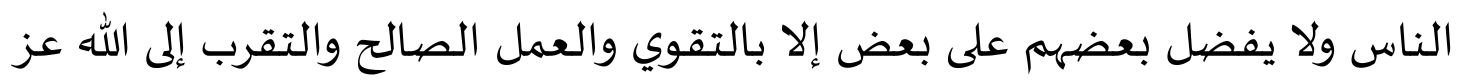

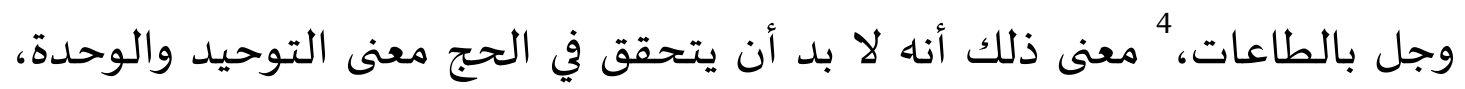

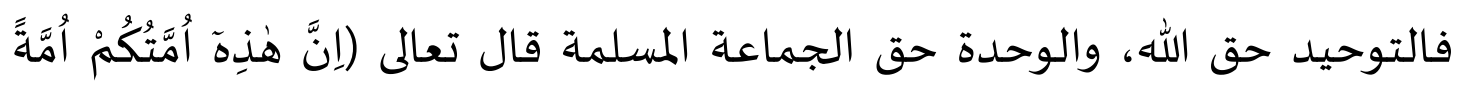

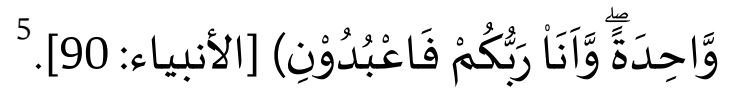

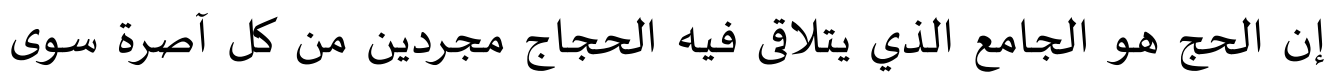

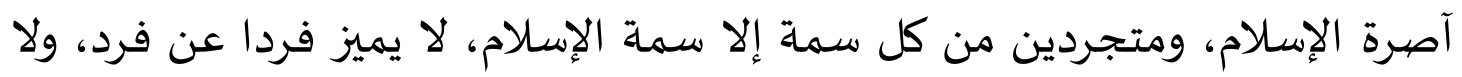

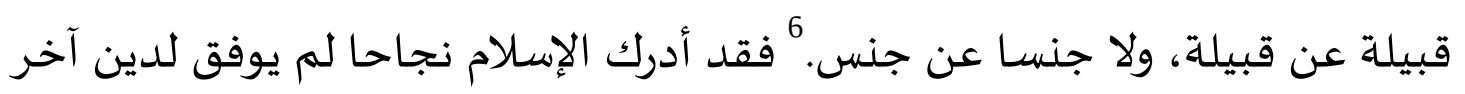

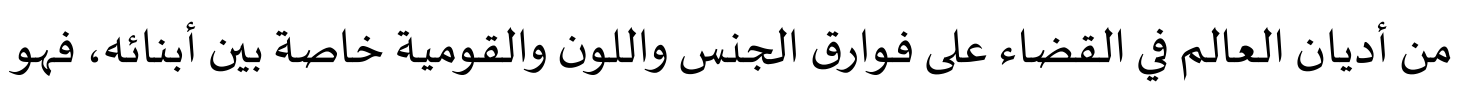
لا يعترف بفاصل بين أفراد البشر إلا الذي يقوم بين المؤمنين وبين غير المؤمنين، ولا لا

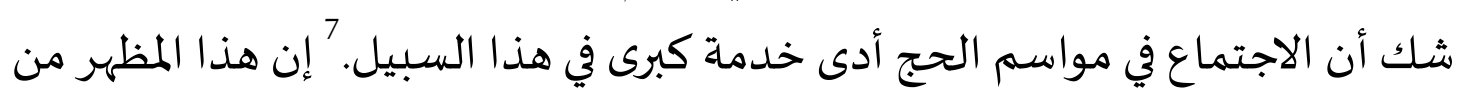
مظاهر الاجتماع البشري لهو أكبر نموذج على الأخوة الإنسانية في أسمى في معانيها،

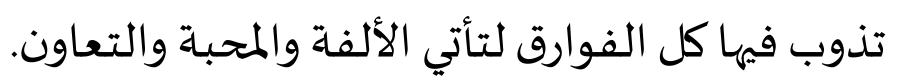

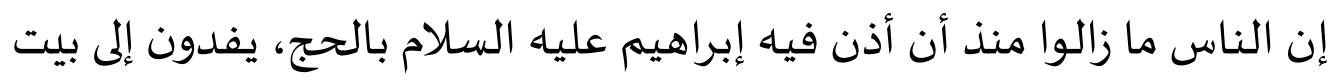
الله الحرام في كل عام من أصقاع الأرض كلها، وأرجاء المعمورة جميعها، مختلفة إنة إنهاء

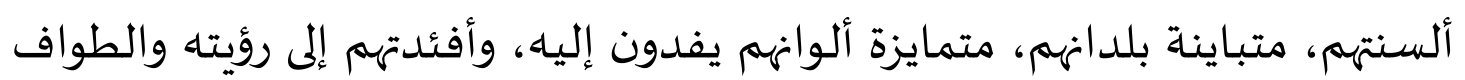

${ }^{4}$ Mușțafā La'zūzī, Thaqāfah al-Hāajjj 'Ibādah wa Akhlāk, Fannun wa Indịbāt, 1st ed. (Beyrūt: Dār al-Kutub al-'Ilmiyyah, 2006).

${ }^{5}$ Nāṣir al-Zahrānī, İhāj al-Hājjj, 3rd ed. (Egypt: al-Maktabah al-Waqfiyyah, 1995), p. 71.

${ }^{6}$ Sayyid Husayn al-'Affānī, Al-Riyāẹ al-Nazirah fi Faḍāil al-Hājj wa al-'Umrah, 2nd ed. (Maktabah Mu'ādh bin Jabal, 1997), vol. 1, p. 191.

${ }^{7}$ Muhammad al-Sharīf al-Raḥmūn̄̄, Manāsik al-Hājj wa al-'Umrah min al-Qurān wa alSunnah Dirāsah wa Taṭbīq (Tūnis: Dār al-Arabiyyah li al-Kitāb, n.d.), p. 139. 
باه، الغني القادر والفقير المعدم، ومائات الألوف من المسلمين يتقاطرون من فجاج

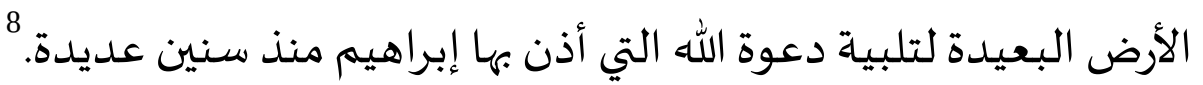

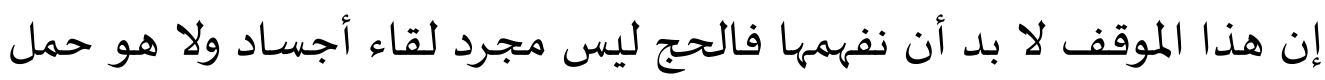

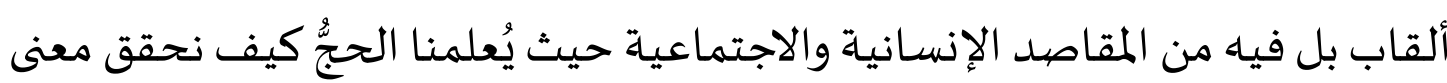

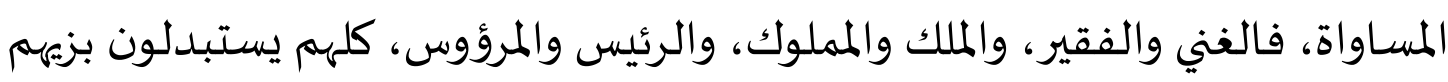

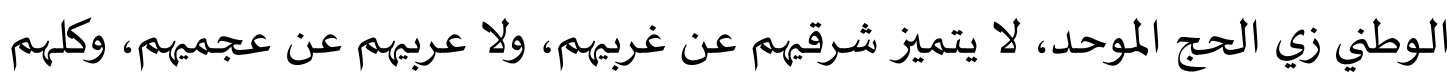

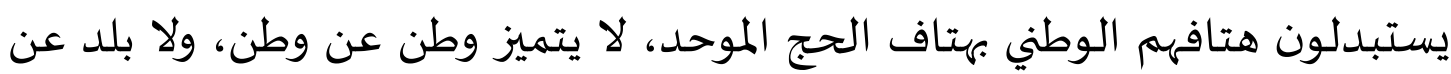
بلد، الكلل أمام الله سواسياة، بل تتراجع هنا كل المعايير والموازين، لا يبقى إلا معيار واحد ومقياس واحد "إن أكرمكم عند الله أتقاكم".

\section{2. تجليات وحدة الأمة في شعيرة الحج}

إن وحدة الأمة تعد من المقاصد العليا في الإسلام، ومن المفاهيم الأساسية

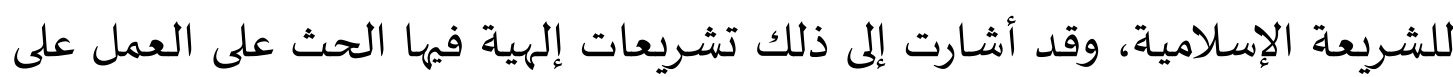
توحيد الأمة وتقويتها وإبقائها سواء في العقيدة أم الأخلاق أم الشريعاتها

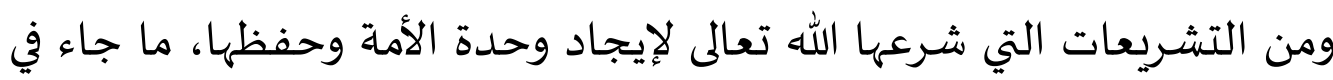

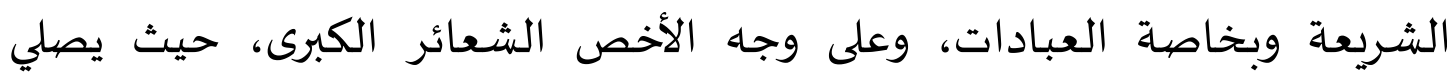

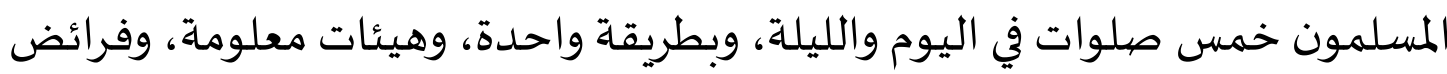

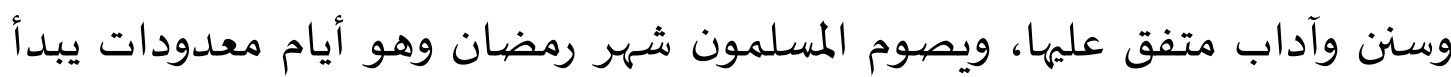

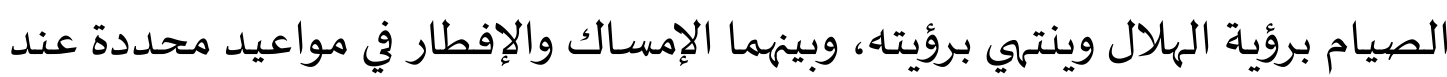

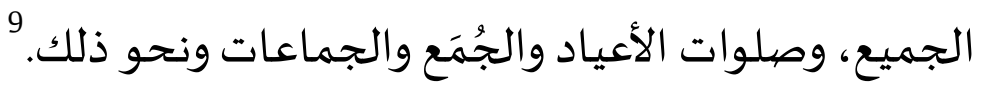

${ }^{8}$ Su'ūd bin Ibrāhīm al-Shuraym, al-Minhāj li al-Mu'tamir wa al-Hāijj, 1st ed. (Riyaḍ: Dār alWațan, 1994), p. 43.

${ }^{9}$ Wașfī 'Āshūr Abu Zayd, Ru'yah Maqāṣidiyyah fi Aḥwāl al-'Așriyyah, 1st ed. (Cairo: Dār alMaqāṣid li al-Ṭibā'ah wa al-Nasyr, 2017), vol. 1, p. 37. 
ومن الشعائر الكبرى الأكثر أهمية في تجلية وحدة الأمة هي شعيرة الحج، بحيث

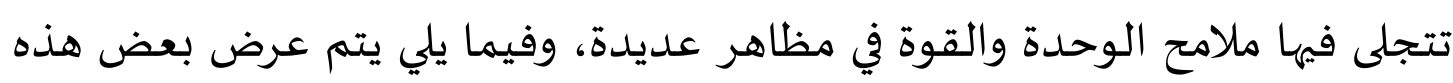

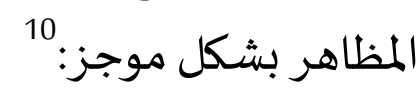

\section{أ) وحدة الوجهة والمقصيد}

من مظاهر الوحدة في شعيرة الحج هو وحدة الوجهة والقصد، فقد جاء في

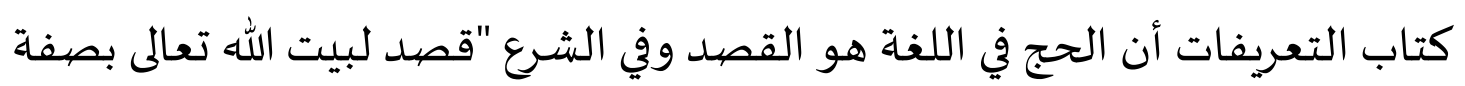

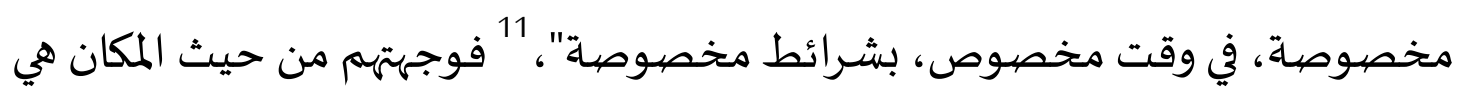

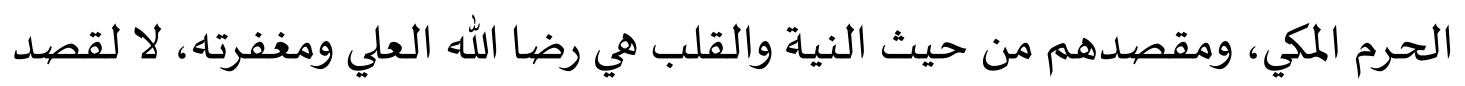

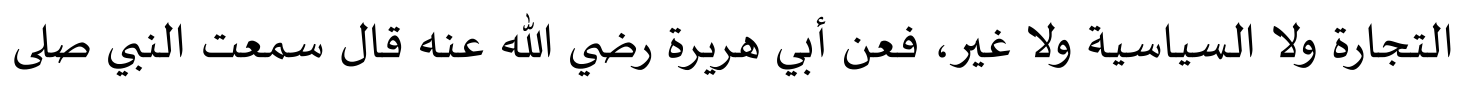

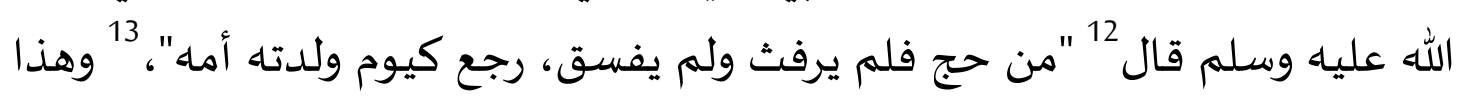

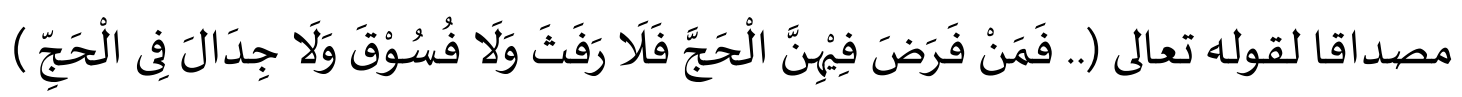

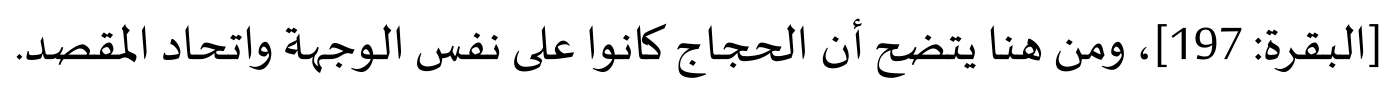

$$
\text { ب) وحدة في المظهر }
$$

إن المرء لا يرتدي ثياباه، ولكن ثيابه هي التي تغطيه، فملابسنا هي التي تعبر عن

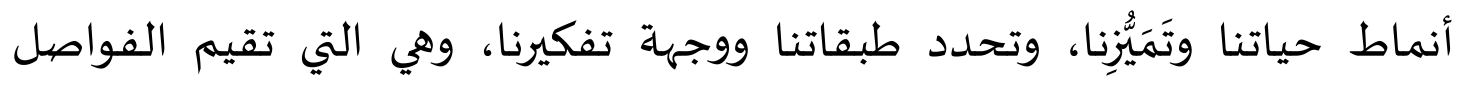

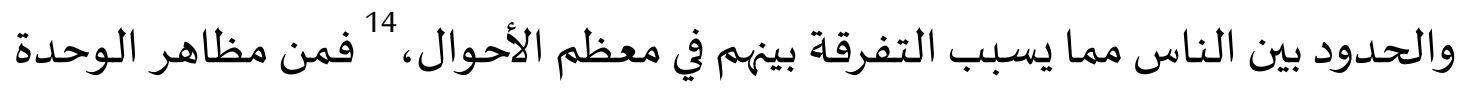

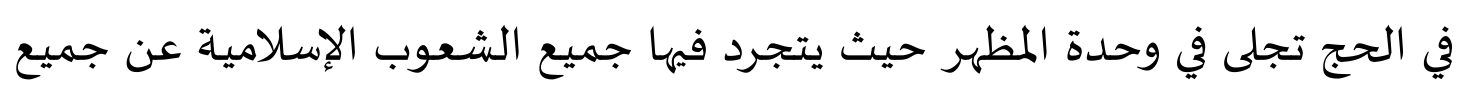

${ }^{10}$ Abū Zayd, Ru'yah Maqāṣidiyyah fi Aḥwāl al-'Așriyyah, vol.1, p. 42-37.

11 'Alī bin Muhammad bin 'Alī al-Zayn al-Sharīf al-Jurjānī, al-Ta'rīfāt, 1st ed. (Beyrūt: Dār al-Kutub al-'Ilmiyyah, 1883), p. 82.

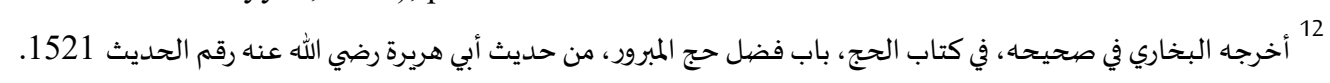

${ }^{13}$ Abū Abdillah Muhammad bin Ismā’̄îl al-Bukhārī, al-Jāmi' al-Ṣahịh (Cairo: al-Maktabah alSalafiyyah, 1440), vol. 1, p. 471.

14 'Ali Sharī’atī, al-Farị̣̄ah al-Khamsah, 2nd ed. (Giza: Dār al-Asmā, 1992), p. 31. 
ملابسها وأزيائها الإقليمية التي تميز بعضها عن بعض ويتعصب لها الأقوام، وتظهر

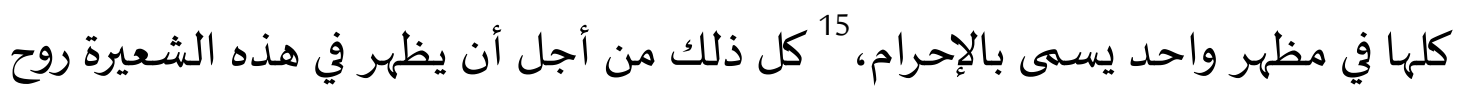
المساواة بحيث يستوي فيها الغني والفقير، العربي والعجمي، الأبيض والأسود، كلهريم

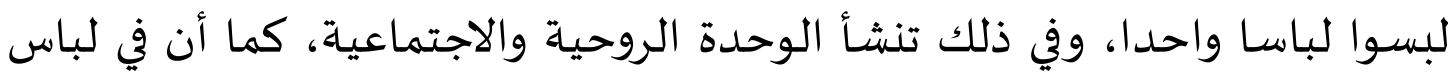
الإحرام المُوَحَّد الخالي عن التجمل والتباهي إبعادهم عن أنانيتهم وتفاخرهم وتعاليهم.

\section{ج) وحدة المكان والزمان}

من مظاهر الوحدة في الحج هو وحدة المكان والزمان، وفي ذلك يقول سبحانهاء

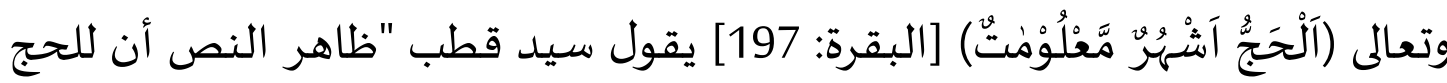

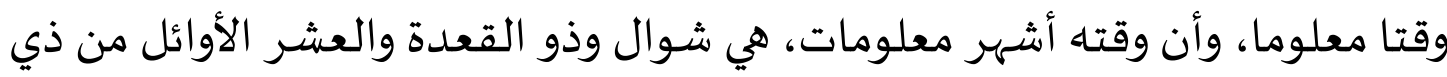

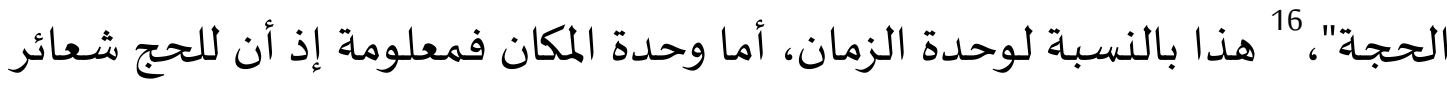

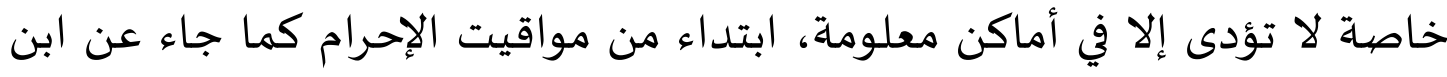

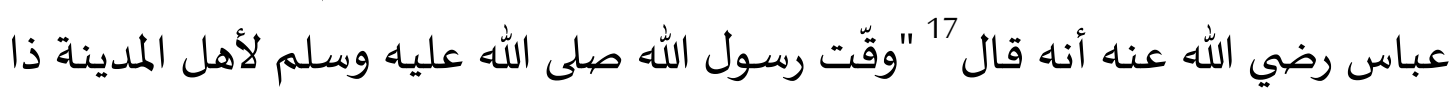
الحليفة، ولأهل الشام الجحفة، ولأهل نجد قرن المنازل، ولأهل اليمن يلملم، فهن لهن الهن

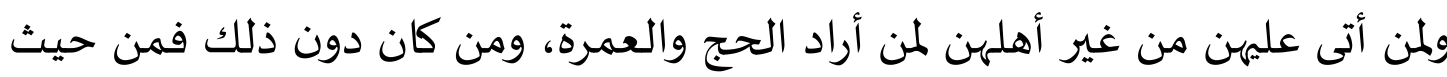

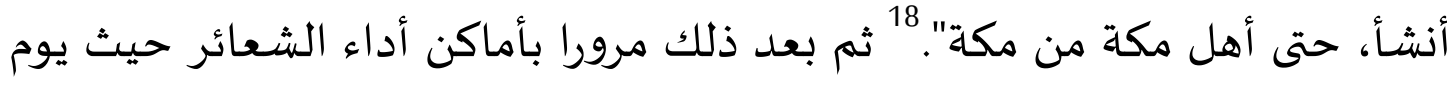

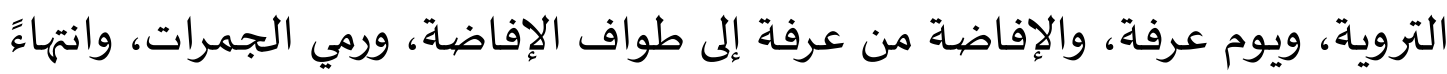
بطواف الوداع.

${ }^{15}$ Abū al-Hasan 'Ali al-Ḥasanī al-Nadawī, al-Arkān al-Arba'ah (al-Șalāh, al-Zakāh, al-Șawm, al-Hājj) fi Daw'i al-Kitāb wa al-Sunnah Muqāranah Ma'a al-Diyānāt al-Ukhrāa (Cairo: Dār al-Kutub al-'Ilmiyyah, 1387), p. 247.

${ }^{16}$ Sayyid Quṭb, fì Zilāl al-Qurān (Beyrut: Dār al-Shurūq, 2003), vol. 1, p. 196. 17 أخرجه البخاري في صحيحه، في كتاب الحج، باب مهل أهل مكة للحج والعمرة، من حديث ابن عباس رضي الله عنهما، رقم

${ }^{18}$ al-Bukhārī, al-Jāmi' al-Ṣaḥịh, vol. 1, p. 471.

${ }^{19}$ Abū Zayd, Ru'yah Maqāṣidiyyah fì Aḥwāl al-'Așriyyah, p. 40. 


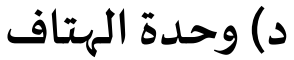

من مظاهر الوحدة في شعيرة الحج هو وحدة الهتاف، ويتجلى ذلك عندما

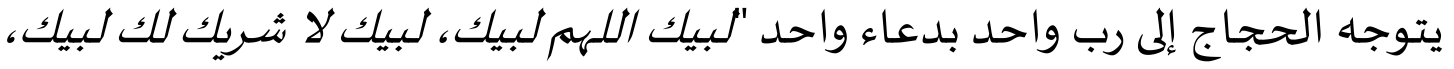

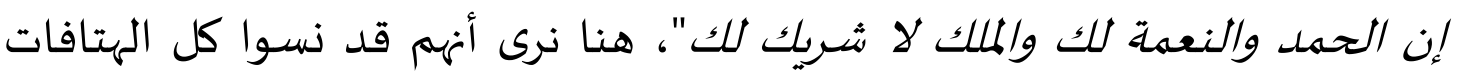

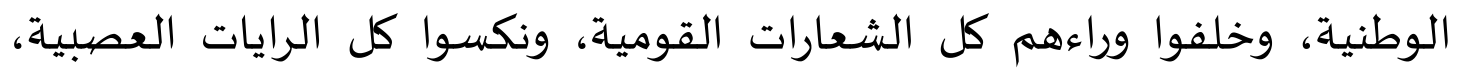

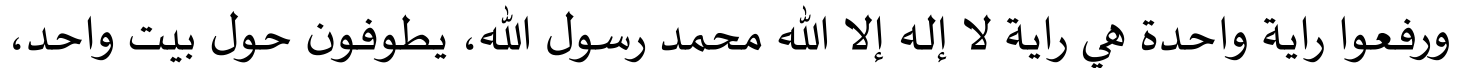
مختلطة أجناسهم وألوانهم ولغاتهم يؤدون نسكا واحد الهدا. 20

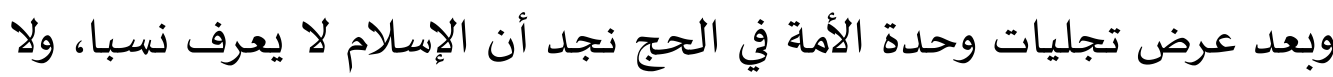

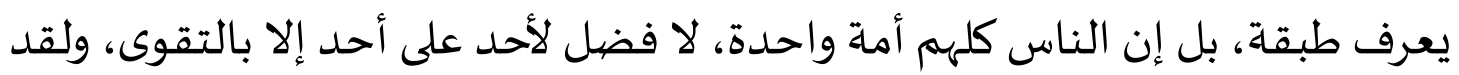

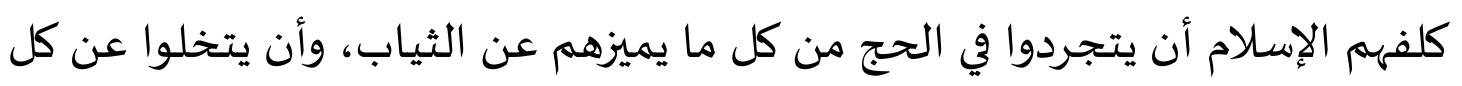

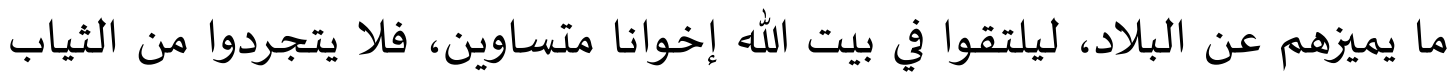

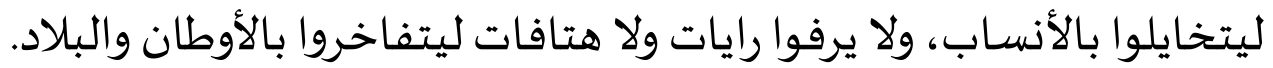
3. العصبية القومية من عادات الجاهلية في الحج

لقد جاء الإسلام في مجتمعات متصارعة منقسم بعضها على بعض، ينقسم

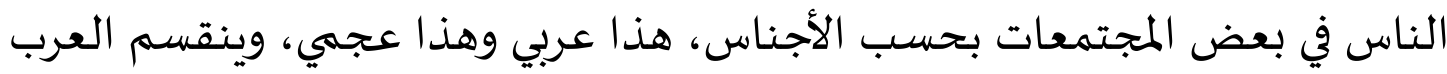

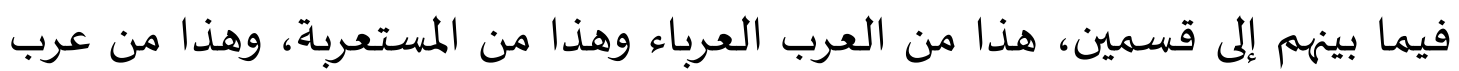

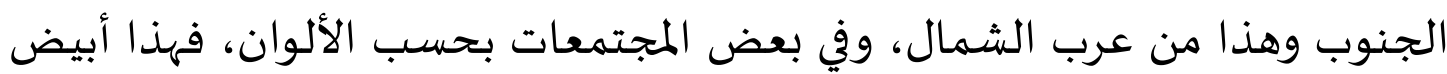

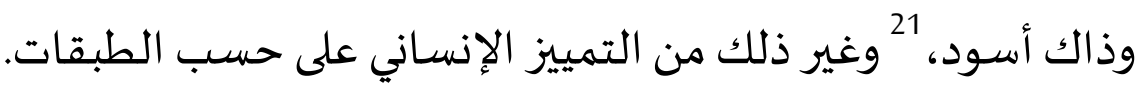
وكان عند العرب عادات جاهلياة، منها اعتزازهم بالعصبية القومياة، وافتخارهم بالأحساب والأنساب، فقد كانت قريش يترفعون عن أن يقفوا مع الناس في عرفة،

${ }^{20}$ al-Shuraym, al-Minhāj li al-Mu'tamir wa al-Hājj, p. 43.

${ }^{21}$ Khālid Khalīfah al-Sa'ad, Khutab Shaykh al-Qaraḍ̄ww̄̄ (Cairo: Maktabah Wahdah, n.d.), p. 51. 
وكانوا يقولون "نحن أهل الله وسكان حرمه، فلا نخرج من الحرم، ولا نرضى أن نكون

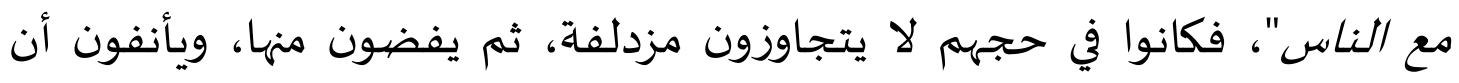
يفيضوا من عرفات.

ونقل في ذلك رواية عن عائشة رضي الله عنها أنها قالت 23 "كان قريش ومن دان دينها يقفون بالمزدلفة، وكانوا يسمون الحُمْسَ، وكان سائر العرب يقفون بعرفة، فلما

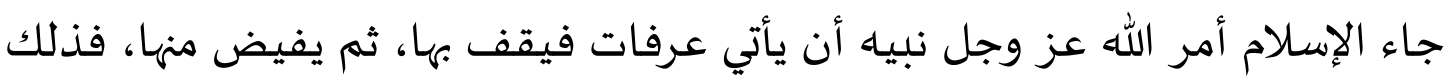

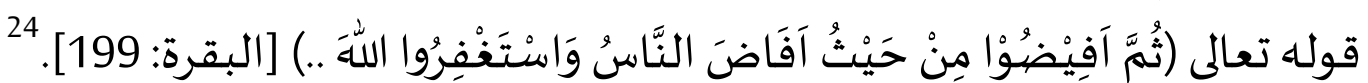

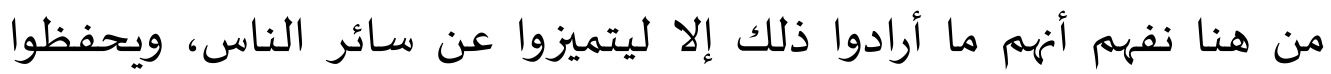
مركزهم الجاهلي، وعلى ما كانوا يتخيلونه من سمو وامتياز، فأبطل الله هذا الامتياز

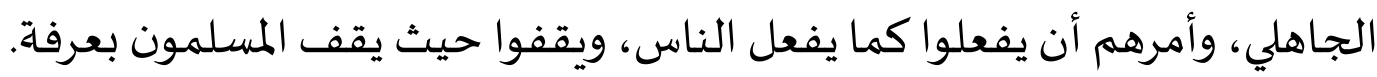

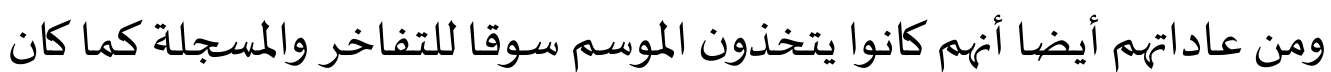

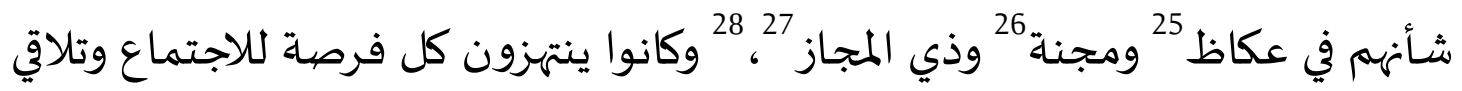

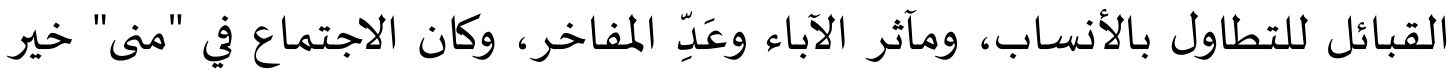

${ }^{22}$ Muhammad 'Ali al-Ṣābūnī, Qabas min Nūr al-Qurān, 2nd ed. (Damaskus: Dār al-Qalam, 1988), vol. 1, p. 51.

23 أخرجه مسلم في صحيحه، في كتاب الحج، باب في الوقوف وقوله تعالى (ثم أفيضوا من حيث أفاض الناس)، من رواية عائشة

رضي الله عنها، رقم الحديث 1219.

${ }^{24}$ Abū al-Ḥusayn Muslim bin al-Ḥajjjāj, Șaḥihh Muslim, 2nd ed. (Riyaḍ: Dār al-Ṭayyibah, 2006), vol. 2, p. 559.

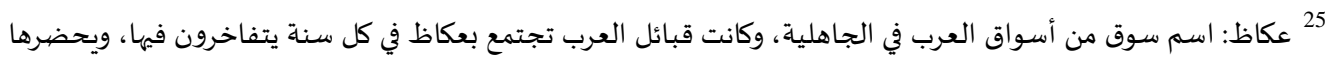

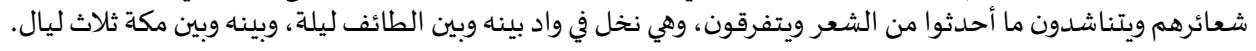

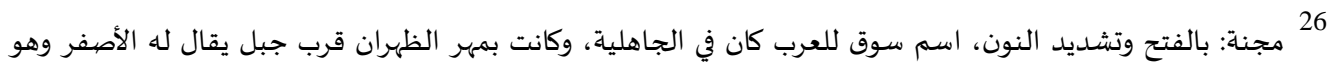

بأسفل مكة على قدر بريد منها.

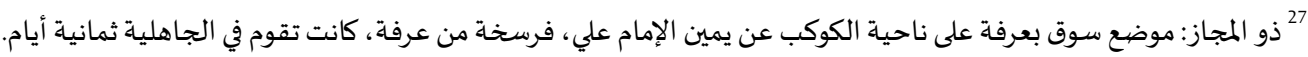

${ }^{28}$ Shīhāb al-Dīn Abū Abdillah Ya'qūt al-Ḥamawī, Mu'jam al-Buldān (Beyrut: Dār Ṣādir, 1977), vol. 4 , p. 142 , vol. 5 , p. 55,70 . 
مكان لإرضاء العاطفة الجاهلية، فهاهم الله عن ذلك وأبدل لهم خيرا منه وهو ذكر اللهـ.

وقد ورد في ذلك أثر عن ابن عباس رضي الله عنه أنه قال "كان أهل الجاهلية

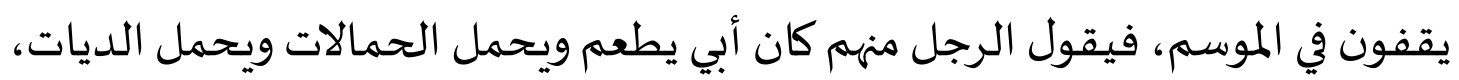

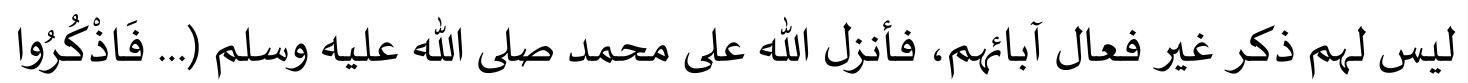

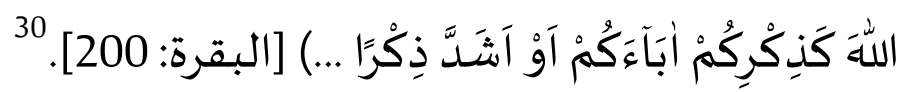

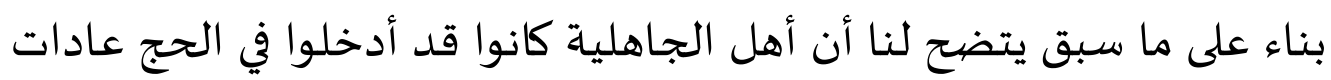

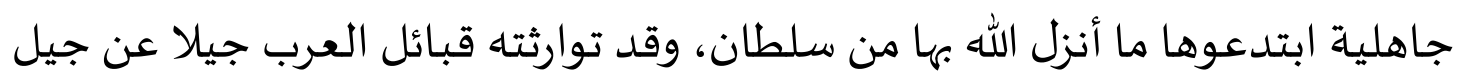

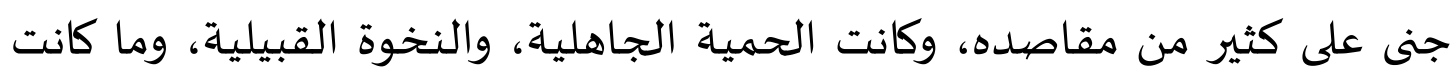

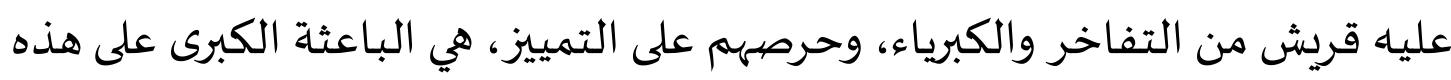

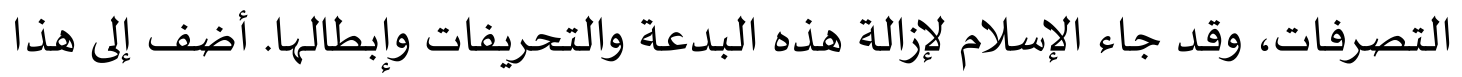

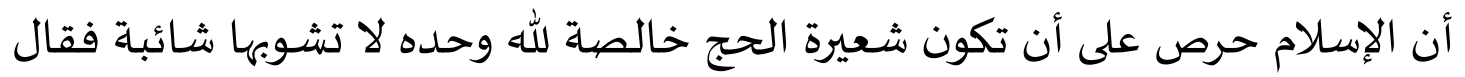

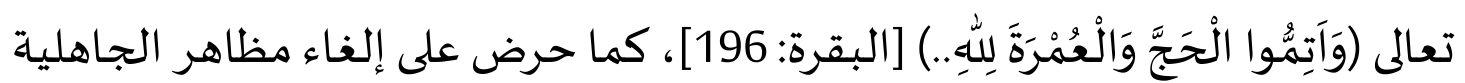

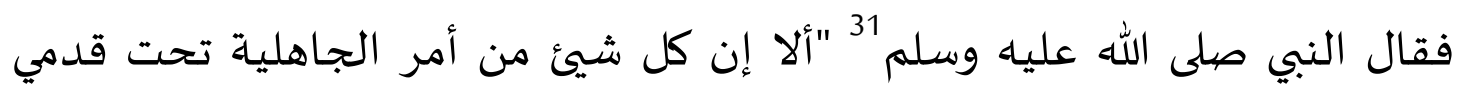
موضوع"

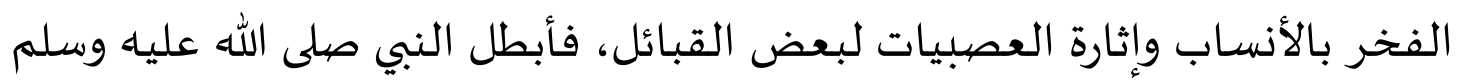

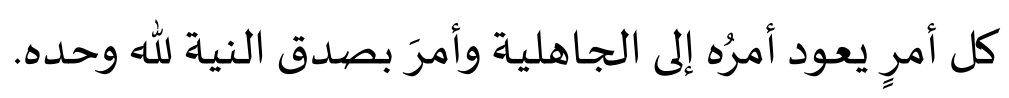

${ }^{29}$ al-Nadawī, al-Arkān al-Arba'ah (al-Șalāh, al-Zakāh, al-Șawm, al-Hāājj) fì Ḋaw'i al-Kitāb wa al-Sunnah Muqāranah ma'a al-Diyānāt al-Ukhrā, p. 270.

${ }^{30}$ Abū al-Fidā Ismā'īl Ibn Kathīr, Tafsīr al-Qurān al-'Az̄im, 1st ed. (Beyrut: Dār Ibn Hazm, 2000), vol. 1, p. 263.

31 أخرجه مسلم في صحيحه في كتاب الحج، باب حجة النبي صلى الله عليه وسلم، من حديث جابر بن عبد الله رضي الله عنهما،

رقم الحديث 1218.

32 al-Ḥājjāj, Șaḥịh Muslim, p. 557. 


\section{4. حب الوطن فطرة إلهية وفريضة دينية}

إن فكرة الوطن قامت على حاجة الناس إلى المكان وارتباطه به، وهذا أمر

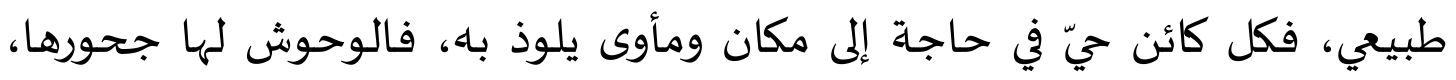

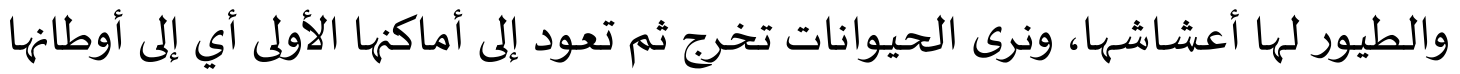

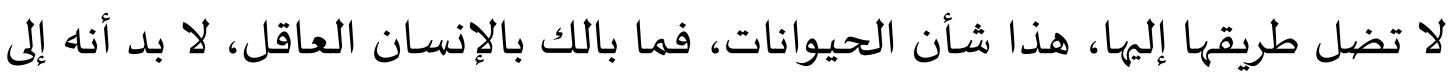

$$
\text { الوطن الذي يربطه أحوج إلياه. }
$$

إن حب الوطن من الميول الفطرية والطبيعياة، بل إن الإسلام يراعي هذه إنهاء

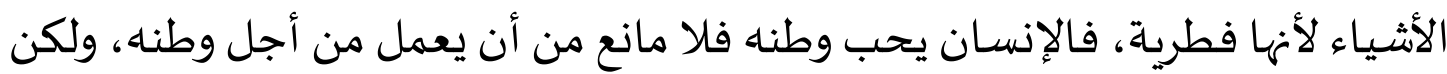

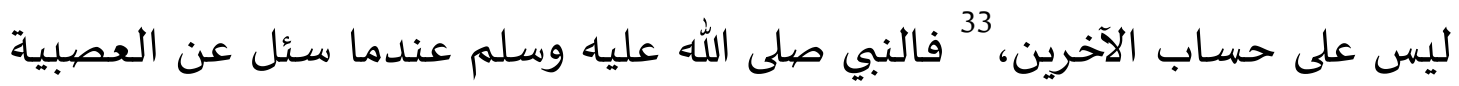

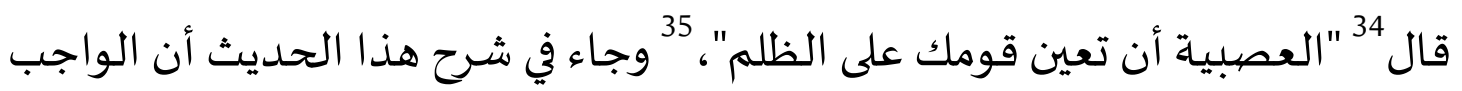
عليك هو متابعة الحق من غير نظر إلى الخلق، ومن أجل ذلك قال النبي صلى الله عليه

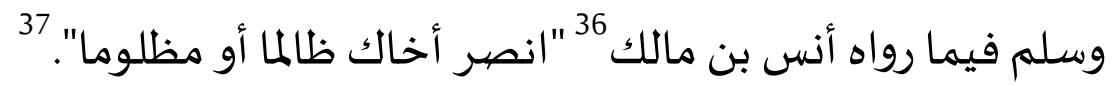

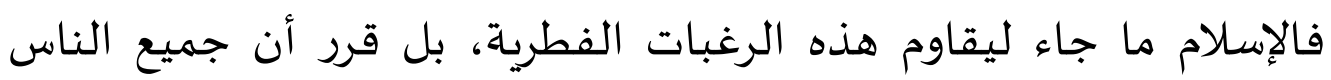

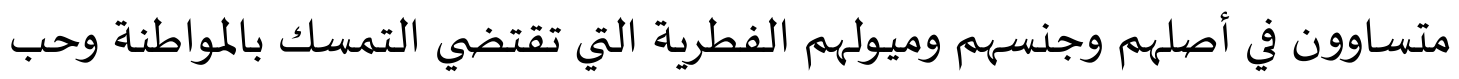

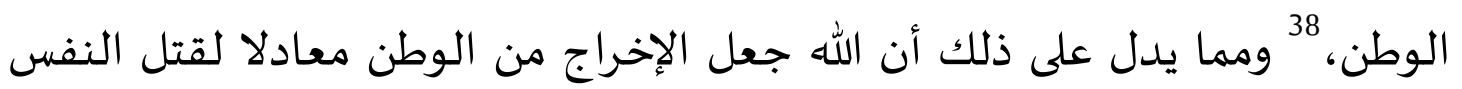

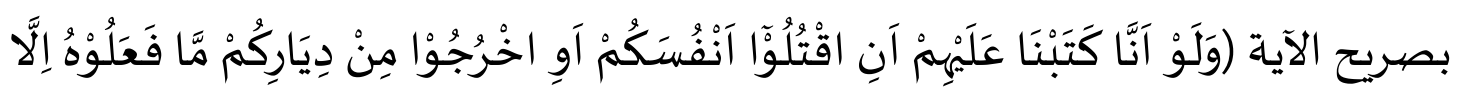

${ }^{33}$ A. Zamakhsyari Baharuddin, "Pengawasan Terhadap Acara Televisi Dalam Perspektif Fiqh Islami dan UU No. 32 Tahun 2002 Tentang Penyiaran Indonesia” (Syarif Hidayatullah State Islamic University Jakarta, 2017), p. 229.

$$
\text { 34 أخرجه أبو داود في سننه، كتاب الأدب، باب في العصبية، من حديث وائلة بن الأسقع رضي الله عنه، رقم الحديث } 5074 .
$$

35 Abū Dawd Sulaymān bin Ash'as al-Sajistānī, Kitāb Sunan, 1st ed. (Jeddah: Dār al-Qiblah, 1998), vol. 5, p. 406.

$$
\begin{aligned}
& 36 \text { أخرجه البخاري في صحيحه، كتاب المظالم، باب أعن أخاك ظالما أو مظلوما، من حديث أنس بن مالك رضي الله عنه، رقم } \\
& \text { الحديث } 2442 .
\end{aligned}
$$
No. 32 Tahun 2002 Tentang Penyiaran Indonesia”, p. 230. 
قَلِيْلِق مِنْهُهُ ..) [النساء: 66] فالتمسك بالوطن والانتماء الوطني غريزة أو نزعة إنسانية

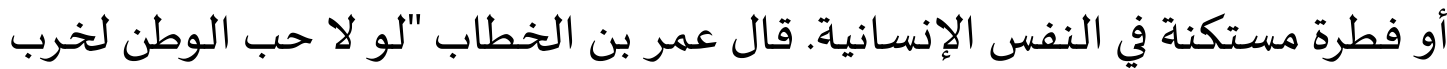
بلد السوء"، 39 أي أن الوطنية ملازمة للإنسان، حتى ولو كان البلد فقيرا وأهله أشرارا.

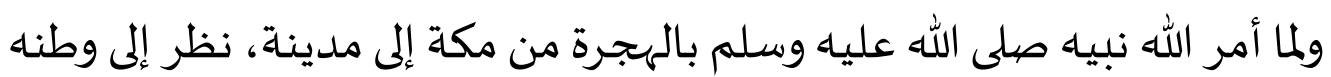

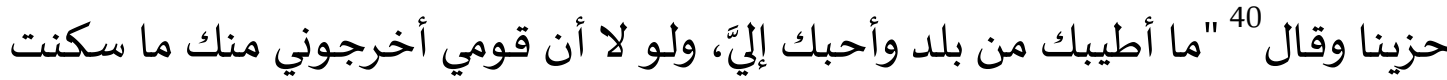

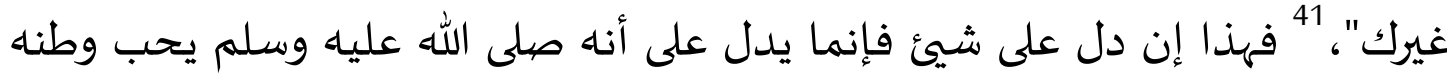

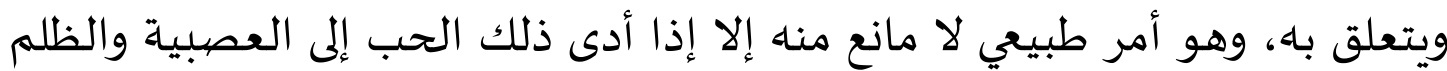

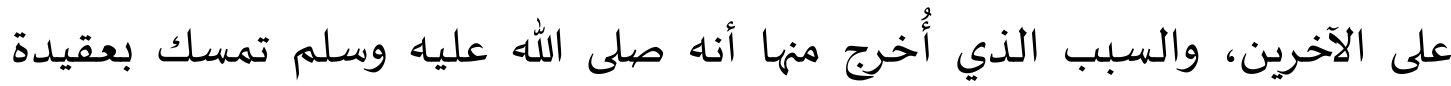

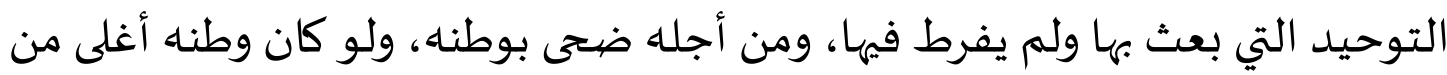
عقيدته لتنازل عنها حتى لا يفقد وطنه. علاوة على ذلك فإن حب المسلم وطنهاه بالمعنى الإقليمي الضيق لا يمنع من حبّه للأمة الإسلامية بصفة عامة، فالإسلام جعل حدود المواطنة أوسع من الحدود الجغرافية الإقليمية الضيقة، ولكن فليحذر المسلم غلو النزعة الوطنية والعصبية القومياة التي قد تجعله يفكر في وطنها قبل عقيدتاه، وفي شعبه قبل أمتاه، فتنبع عنها

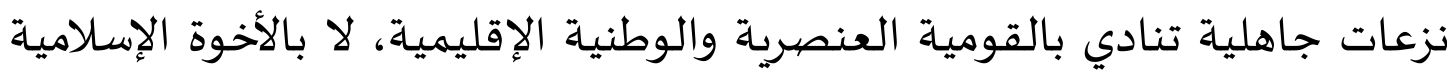

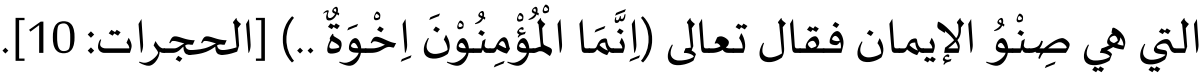
بناء على ما سبق فإن الإسلام حث على حب الوطن، وأقر بأنه فطرة إنسانية،

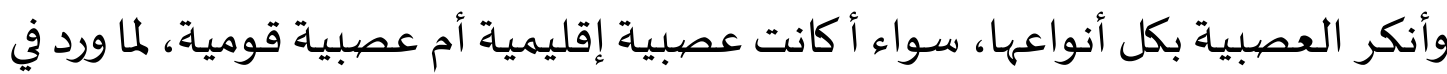

${ }^{39}$ Șālih Rūbīn Andī, Rawā'i al-Hikam min Hadīth al-'Arab wa al-'Ajam (Dubay: al-Manhal, 2013), p. 104.

$$
\begin{aligned}
& 40 \text { أخرجه الترمذي في صحيحه، في كتاب المناقب عن رسول الله صلى الله عليه وسلم، باب في فضل مكة، من حديث ابن عباس } \\
& \text { رضي الله عنهما، رقم الحديث } 3926 .
\end{aligned}
$$
n.d.), p. 880 . 
ذلك عن رسول الله صلى الله عليه وسلم أنه قال 42 "من قاتل تحت راية عمياة، يغضب لعصببة، أو يدعو إلى عصببة، أو ينصر عصبية فقتل، فقتلته جاهلية". 43

\section{5. الحج شعيرة دينية وعبادة جماعية}

إن ديننا هو دين الجماعاة، فهو يأمرنا بالاجتماع تحت قيادة واحدة، ويأمرنا

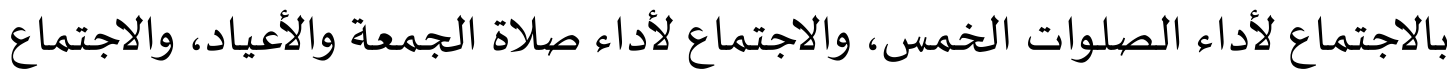

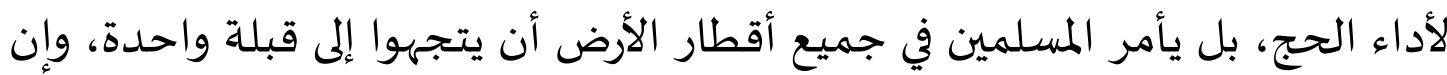

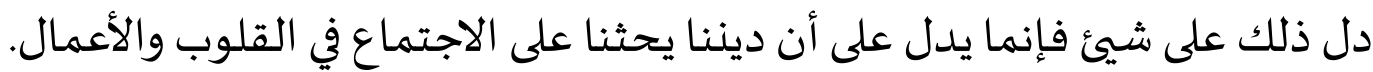
فالاجتماع في الإسلام ليس خيارا، وليس مرحلة، بل هو بيئة دائماة، ونمط لئل

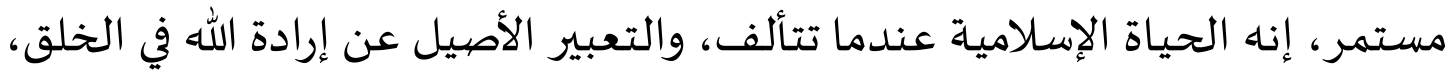

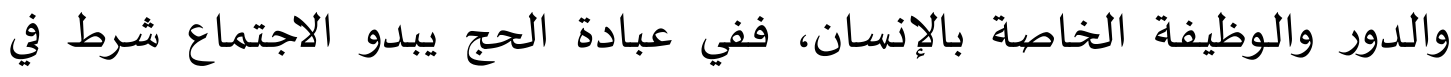

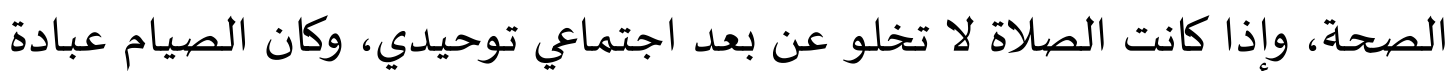
توحيدية اجتماعياة، فإن الحج كله عبادة جماعية، 44 ومعنى ذلك أنها لا لا مكان فيها

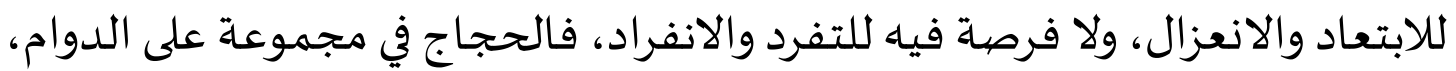
وفي الإحرام والتلبية، وفي الطواف والسعي، وفي الوقوف بعرفات والمبيت عند المزدلفة، وفي كل مكان فيـاه عبادة وتعبد.

إن هذا العنصر الجمعي ركن ركين، من دونه لا يكون الحج حجا، ولا يقع فرضيا ولا نفلا، ولقد حرص الإسلام على هذا التجمع في الحج حرصا يفوق كل حرص، دونه وجعله دئه

\footnotetext{
42 أخرجه النسائي في سننه، في كتاب تحريم الدم، باب التغليظ فيمن قاتل تحت راية عمية، من حديث جندب بن عبد الله رضي

الله عنه، رقم الحديث 4126.

${ }^{43}$ Nașir al-Dīn al-Albāni, Șaḥ̄ḥ Sunan al-Albānī, 1st ed. (Riyāḍ: Maktabah al-Ma'ārif, 1998), vol. 3, p. 103-104.

${ }^{44}$ Maḥmūd Shaltūt, min Tawjīhāt al-Islām, 8th ed. (Beyrut: Dār al-Shurūq, 2004), p. 330.

${ }^{45}$ Hasan Salhab, al-Shaykh Maḥmūd Shaltūt Qirā'ah fi Tajribah al-Iṣlāh wa al-Wiḥdah alIslāmiyyah, 1st ed. (Beyrūt: Markaz al-Haḍarah li Tanmiyah al-Fikr al-Islāmī, 2008), p. 258.
} 
هو الحلقة الختامية العلميا كل عام، يتوّج بها سلسلة التجمعات المحلية التي دعا المسلمين إليها في مختلف المناسبات كالصلوات الخمس والجمعاة والعيدين. 46 فالحج شعيرة دينية هي موسم جامع كبير بل فيها تجمع أكبر من الأقطار

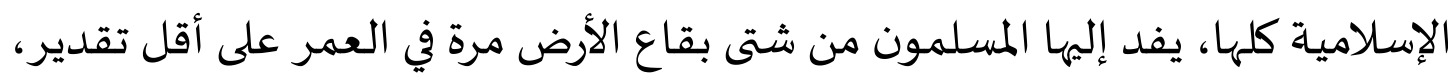

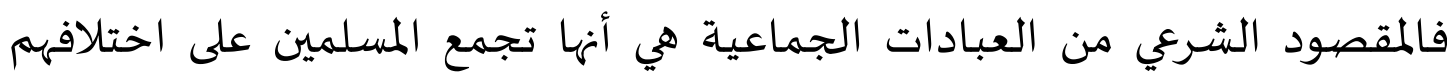

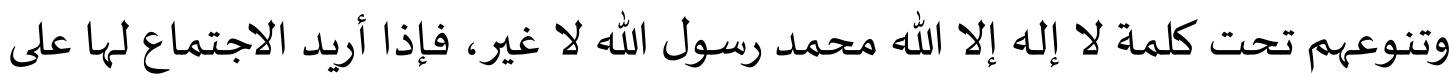

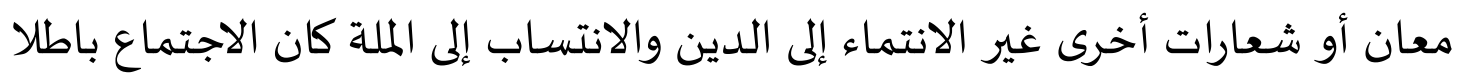

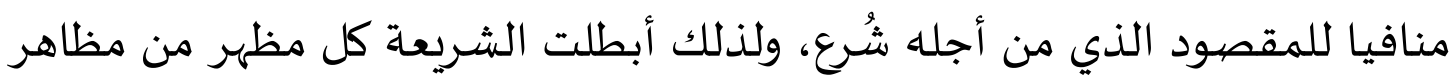

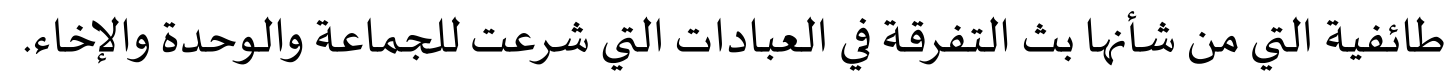

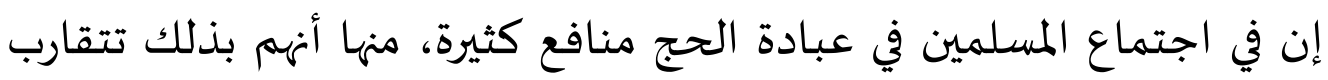

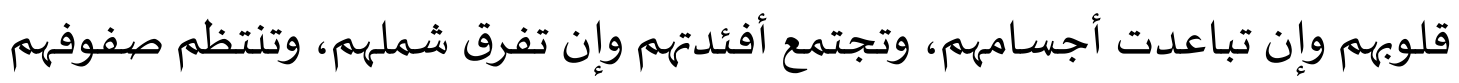

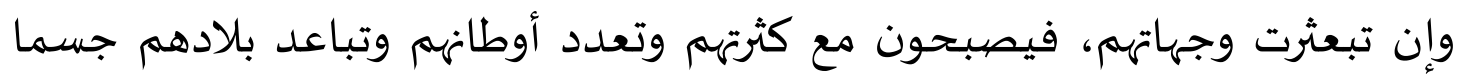

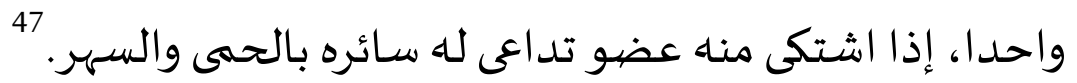

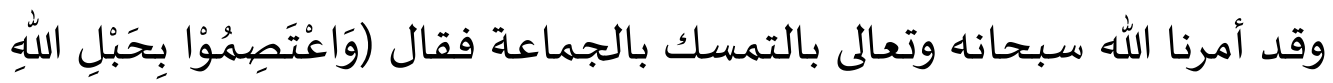
جَمِيْعًا..) [آل عمران: 103] ثم أتبع بعده بنفي ضهده تأكيدا فنهانا عن التفرق فقالتهال

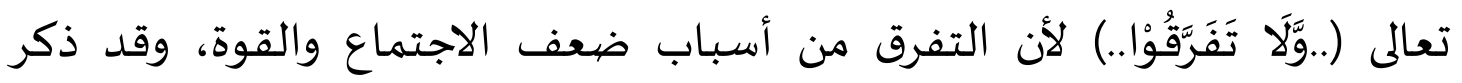

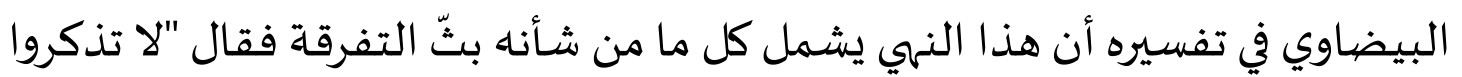

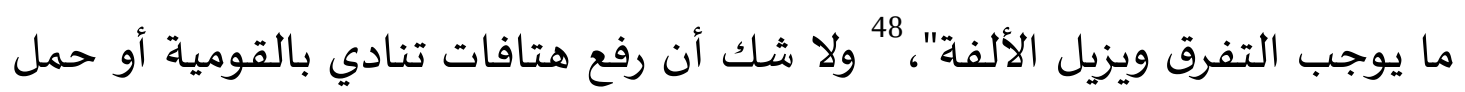
شعارات طائفية عند أداء مناسك العمرة والحج يوجب التفرقة والتنازع والجدال ولتدال والتكالب على الدنيا.

46 'Ādil bin 'Alī al-Shaddī, "Maqāșid al-Ḥājj fĩ al-Qurān al-Karīm," Majallah Jāmi'ah Umm al-Qurā li 'Ulūm al-Sharī'ah wa al-Dirāsah al-Islāmiyyah 44 (1429), p. 44.

${ }^{47}$ Maḥmūd Ibrāhīm Ṭīrah, “al-Ḥājj,” Majallah al-Islām 46 (1354): 2181.

${ }^{48}$ Nāṣir al-Dīn al-Baiḍāwī, Tafsīr al-Baiḍ̄wwì al-Musammā bi Anwār al-Tanzīl wa Asrār alTa'wāl, 2nd ed. (Beyrut: Dār al-Ma'rifah, 2017), p. 194. 
انطلاقا مما سبق تجدر الإشارة هنا إلى أنه ينبغي للحجاج أن يفهموا هذه

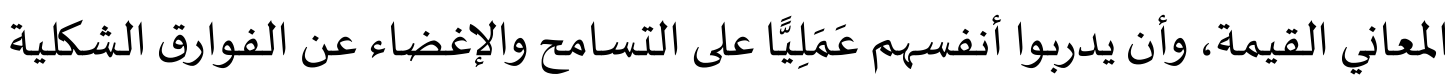

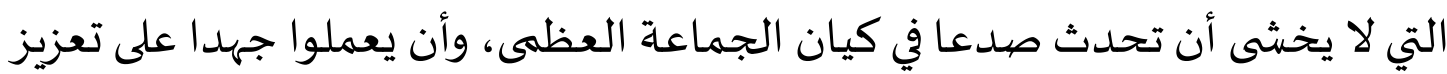

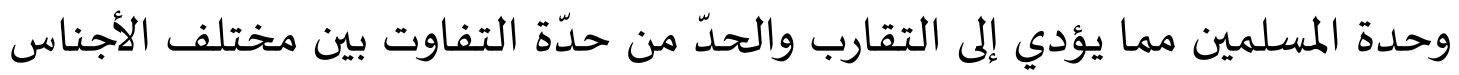

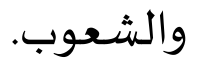

\section{6. - معار الحج التلبية}

إن التلبية شعار الحج فقد ورد في ذلك أحاديث كثيرة، بل إن من عظمتها

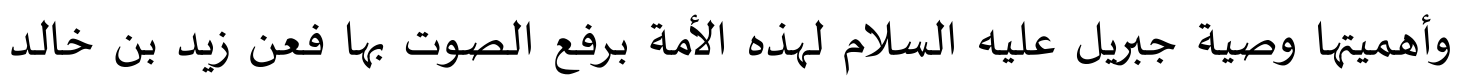

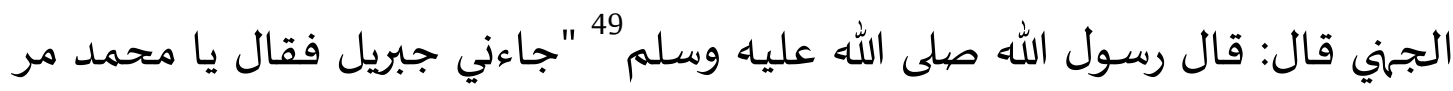

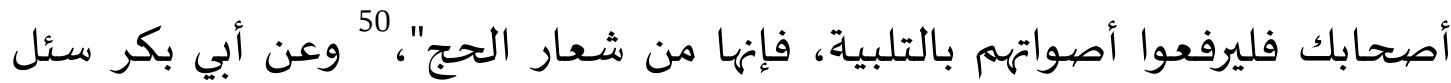

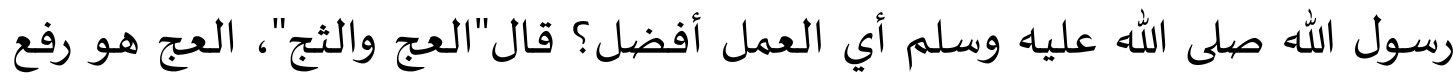

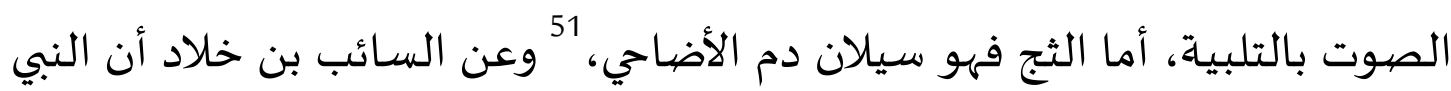

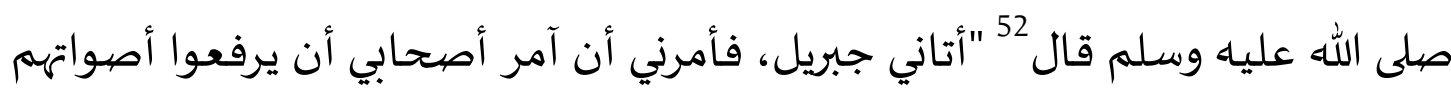
بالإهلال"، 53 والمراد منـه هنا التلبية.

49 أخرجه ابن ماجه في سننه، في كتاب المناسك، باب رفع الصوت بالتلبية، من حديث زيد بن خالد الجهني رضي الله عنه، رقم

50 Muḥammad bin Yazīd al-Qazwīn̄i Ibn Mājah, Sunan (Cairo: Dār Ihyā al-Kutub al'Arabiyyah, n.d.), vol. 1, p. 975.

${ }^{51}$ Badr al-Dīn Aḥmad Abū Muḥammad Mạ̣mūd bin Aḥmad al-'Ayn̄̄, 'Umdah al-Qāri Sharḥ Șaḥ̄h al-Bukhārī, 1st ed. (Beyrūt: Dār al-Kutub al-'Ilmiyyah, 2001), vol. 9, p. 245.

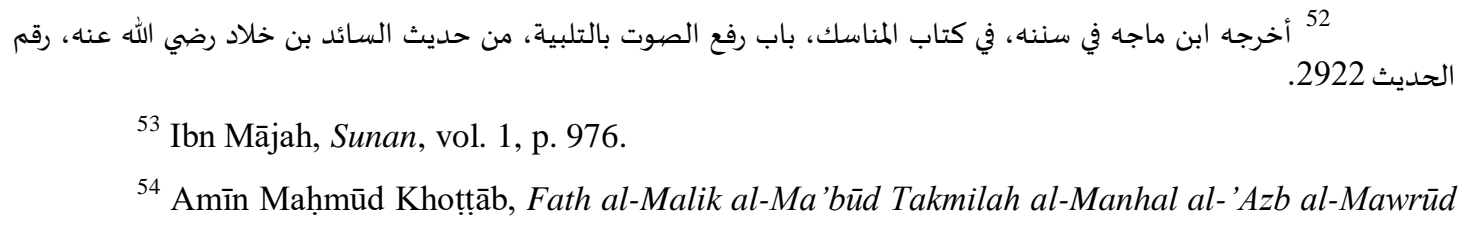
Sharḥ Sunan Imām Ab̄̄ Dawd, 1st ed. (Beyrut: Muassasah al-Tārīkh al-'Arabī, 1974), vol. 1, p. 114. 


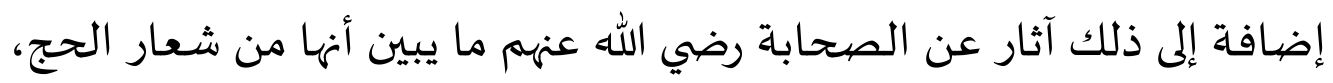
وأنهم ما قاموا بذلك إلا لعلمههم بوصيية جبريل عليه السلام، فكانوا يكثرون منها، ويرفعون أصهواتهم بها، كل ذلك إظهارا لشعائر الله، وتعظيما لها، وإحياء للسنة

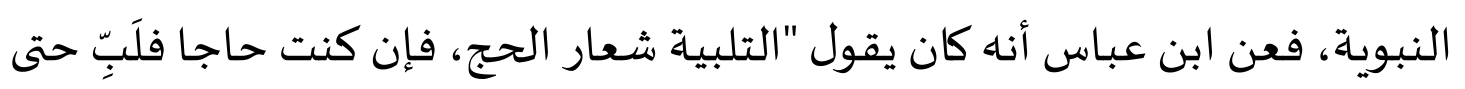

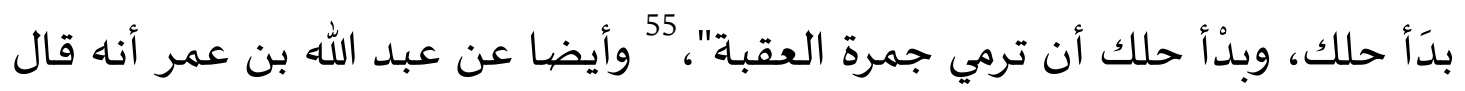
"ارفعوا أصواتكم بالتلبية".

وأعظم من ذلك أن الله شرّف ضيامرا في القرآن لشرف من تحمله وهو الحاج،

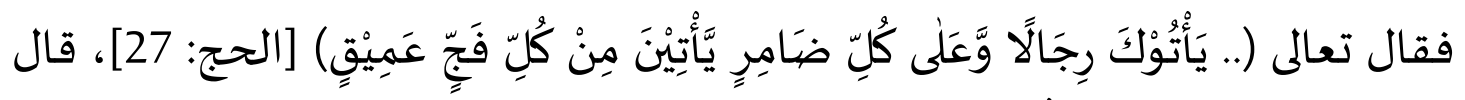

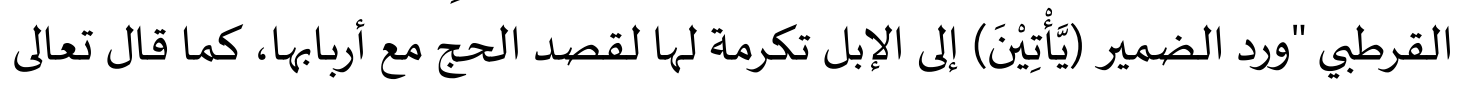

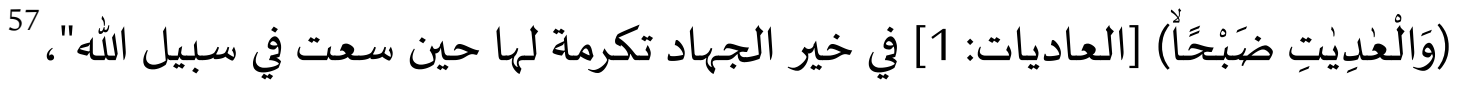

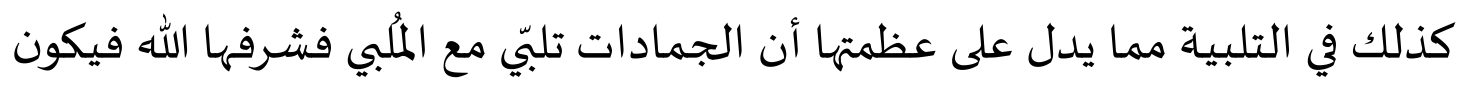
لها حظ من الأجر، وورد في ذلك حديث عن سهل بن سعيد أن النبي صلى الله عليه

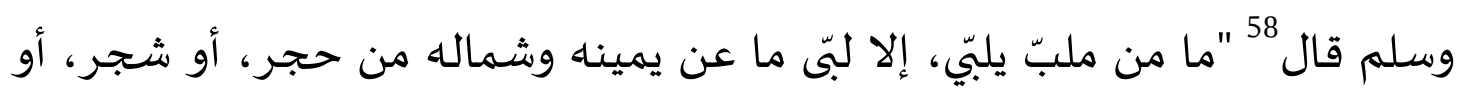
مدر، حتى تنقطع الأرض من ها هنا وها هنا" يعني عن يميناه وشماله. 59

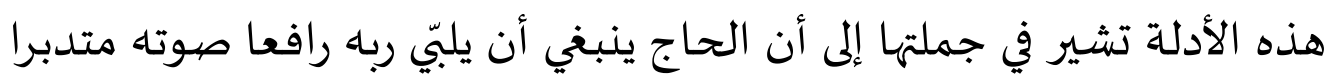

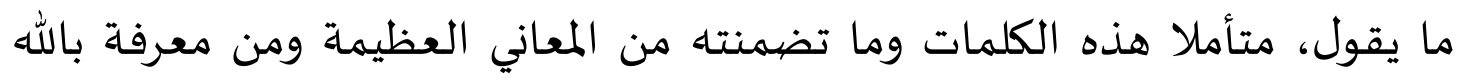

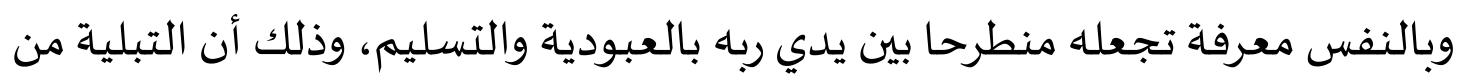

${ }^{55}$ Zāâir Aḥmad al-Uthmānī al-Ṭahānawī, I'lān al-Sunan, 3rd ed. (Pakistan: Idārah al-Qurān wa al-'Ulūm al-Islāmiyah, 1415), vol. 10., p. 117.

${ }^{56}$ al-'Aynī, 'Umdah al-Qārī Sharh Șaḥīh al-Bukhārī, vol. 9, p. 246.

${ }^{57}$ Abū Abdillah Muḥammad bin Aḥmad bin Abī Bakr al-Qurțubī, al-Jāmi' li Aḥkām al-Qurān wa al-Mubayyin limā Tadammanahu min al-Sunnah wa $\bar{A} y \overline{1}$ al-Furqān, 1st ed. (Beyrut: Muassasah alRisālah, 2006), vol. 14, p. 363.

عنهما، رقم الحديث 58 أخرجه البيهقي في سننه، في كتاب الحج، باب التلبية في كل حال وما يستحب من لزومها، من حديث سهل بن سعيد رضي الله

${ }^{59}$ Abū Bakr Aḥmad bin al-Husayn al-Bayhaqī, al-Sunan al-Kubrā, 3rd ed. (Beyrut: Dār alKutub al-'Ilmiyyah, 2003), vol. 5, p. 67. 
شعائر الله الدالة على التوحيد والخضوع والطاعة، ولهذا قال جابر في في حديث طويل مما ثبت في صحيح مسلم ما نصها: فأهل بالتوحيد "لبيك اللهم لبيك، لبيك لا شريك ولك وليك

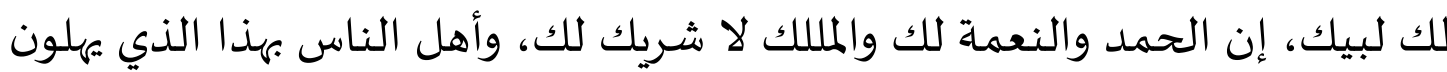

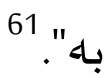

كما يستحب الإكثار من التلبية والاستمرار عليها حال الإحرام، قلا يقطعها إلا عند إرادة الطواف، وتتأكد دبر الصلوات المكتوبة ولو في غير جماعاة، وعند تغير المبله

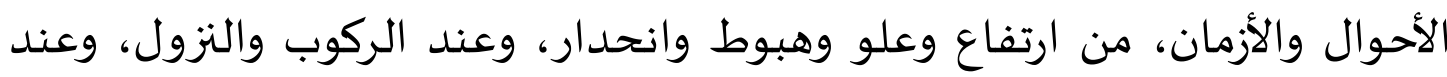

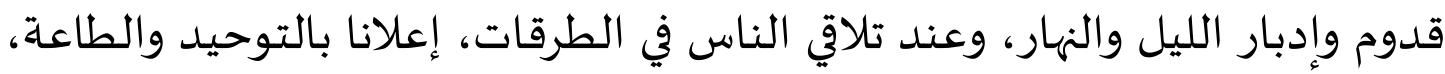

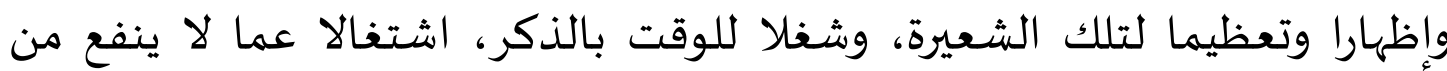

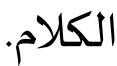

\section{7. فتوى تحريم استخدام الشعارات السياسية في الحج والعمرة}

لقد أصدر دار الإفتاء المصرية بالقاهرة الفتوى بهذا الشأن ما يوضح بيان الحكم الشرعي فيها، وقد أفتوا بتحريمها للأمور التالية أذكرها على سبيل الاختصهار: أ) مخالفتها للمقصود الذي من أجله شرع

إن المقصود الشرعي من هذه الشعيرة أهها تجمع المسلمين تحت اسم الإسلام لا

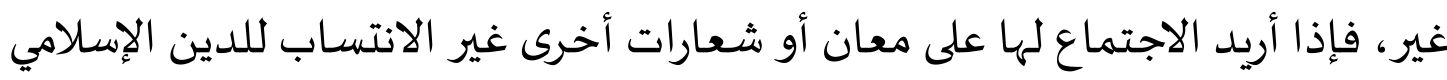

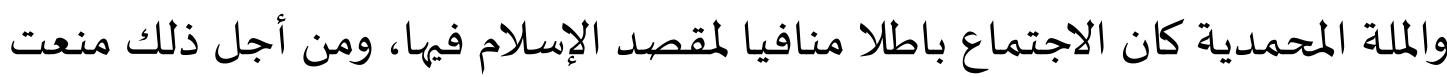

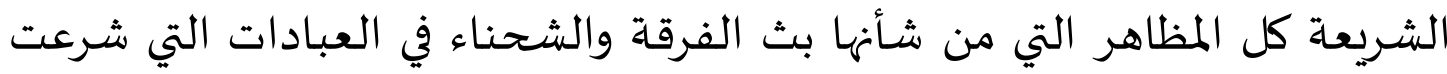

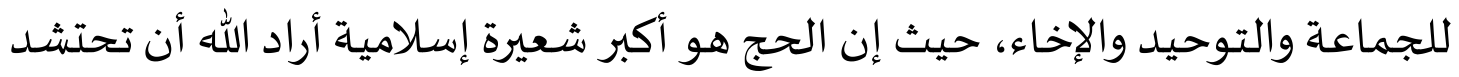

60 أخرجه مسلم في صحيحه، في كتاب الحج، باب حجة النبي صلى الله عليه وسلم، من حديث جابر رضي الله عنه، رقم الحديث

${ }^{61}$ al-Hajjāj, Șaḥịh Muslim, vol. 1, p. 556.

${ }^{62}$ Ibrāhīm Anwār Shawqī, "Istikhdām al-Shi'ārāt al-Siyāsiyyah fī al-Ḥājj," Dār al-Iftā alMișriyyah, 2013, http://www.dar-alifta.org/ar/ViewFatwa.aspx ?ID=13973\&LangID=1\&MuftiType=. 
لها حشود المسلمين وتجتمع فيها كلمتهم ليكونوا أمة واحدة كما وصفهم الله تعالى لتصبح العقيدة الإسلامية والرابطة المحمدية هي المعنى الجامع بينهم شكلا ومضمونها.

\section{ب) ـ هذه الأفعال مدعاة للتفريق بين المسلمين}

لا شك أن رفع الشعارات مناف لمقصيود الاجتماع في العبادات، فالعلة التي من

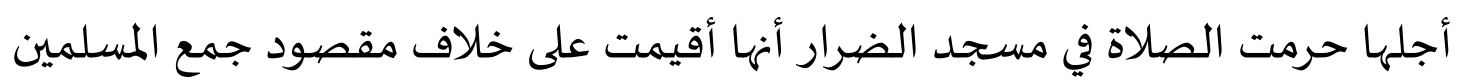

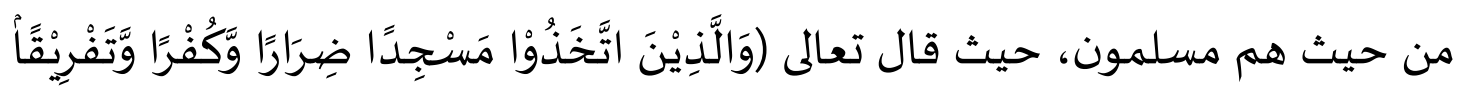

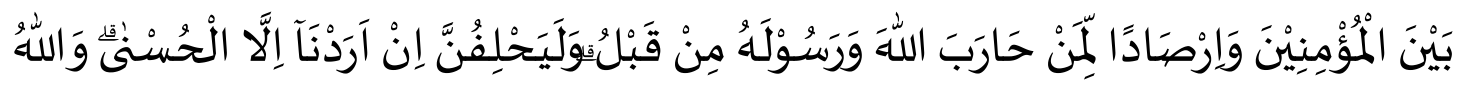

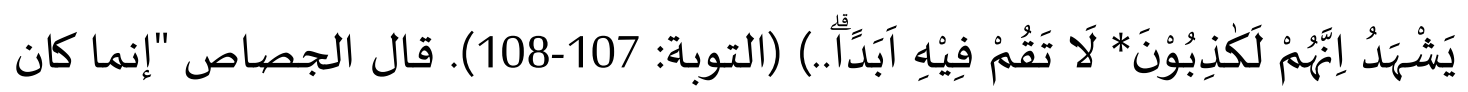

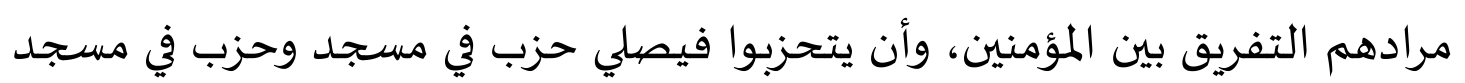

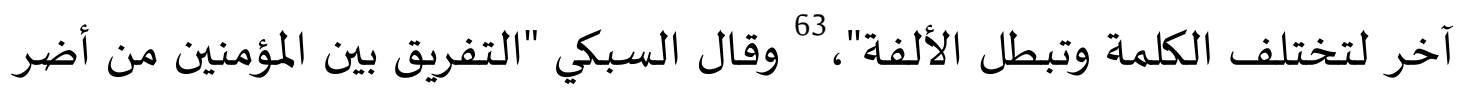

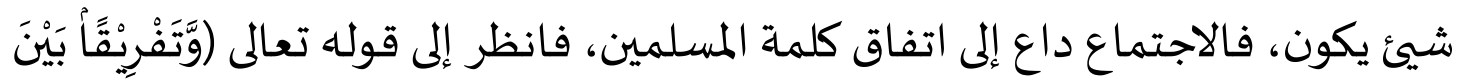

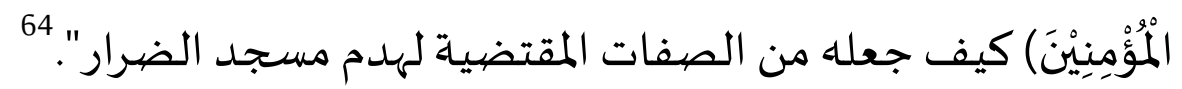

\section{ج) هذه الأفعال تنافي إخلاص العبادة لله}

قال ابن حجر "فالذي يريد في أمر ديني ترويج الأمر الدنيوي من الرياء والسمعة

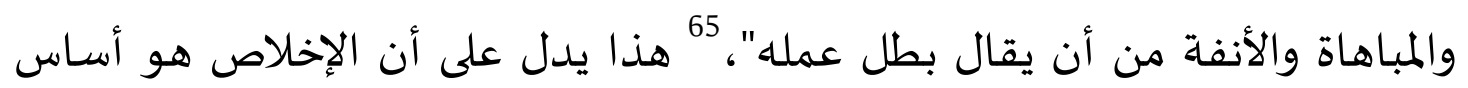

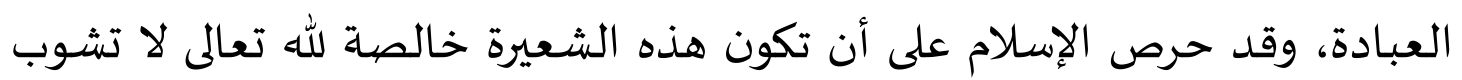

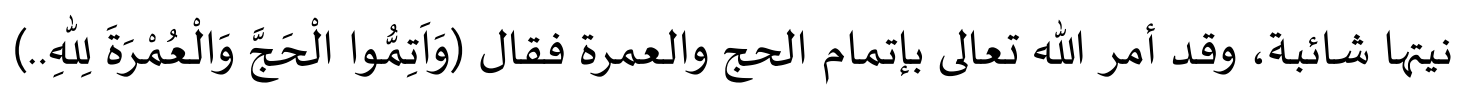

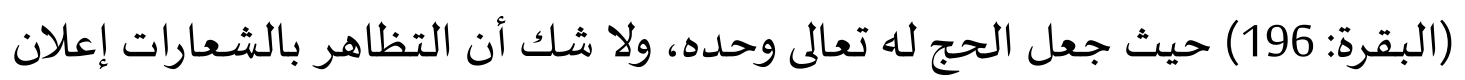

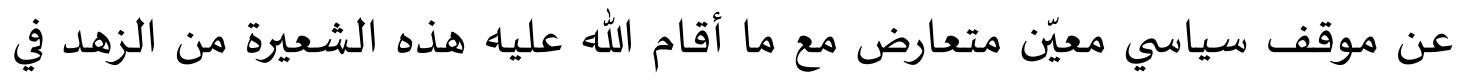

${ }^{63}$ Abū Bakr Aḥmad bin 'Alī al-Rāzī al-Jașṣāṣ, Aḥkām al-Qurān (Beyrut: Dār al-Kutub al'Ilmiyyah, 2012), vol. 3, p. 201.

${ }^{64}$ Abū al-Ḥasan Taqiyyuddīn 'Alī bin Abd al-Kāfī al-Subkī, Fatāwa al-Subkī (Beyrut: Dār alMa'rifah, n.d.), vol. 1, p. 175.

${ }^{65}$ Shawqī, "Istikhdām al-Shi'ārāt al-Siyāsiyyah fī al-Ḥājj." 
الدنيا والتجرد من الأغراض المادية والعادات المألوفة وتخليص النية مما سوى الله تعالى. - م الى

\section{د) فيها إساءة لهذه الشعيرة}

لا شك أن هذه الشعارات في ذاتها لا تليق بمكانة شعيرة الحج وقدسيتها وتنافي

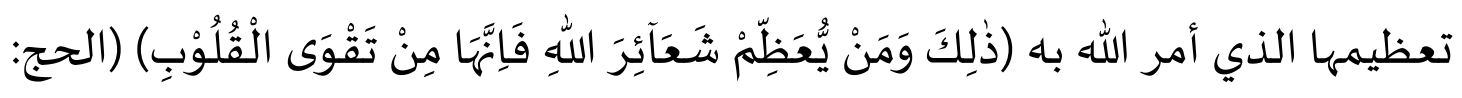

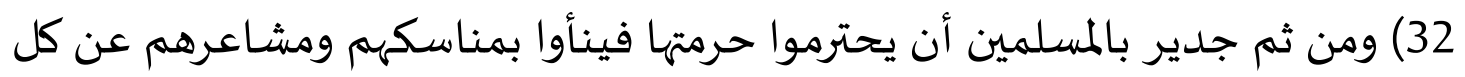

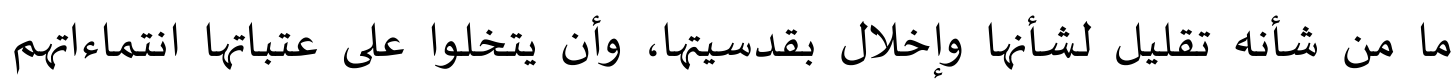

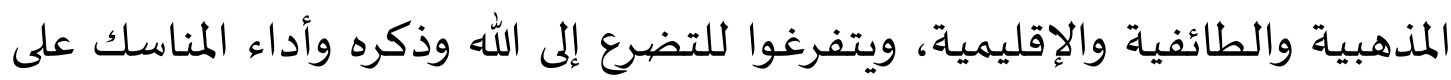
الوجه المرضي.

\section{ه) هذه الشعارات بدعة في الدين مردودة}

إن استغلال الحج لرفع الشعارات والهتافات الطائفية استحداث لأمر لم

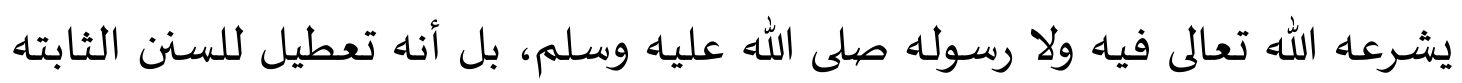

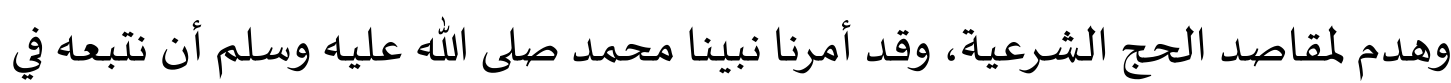

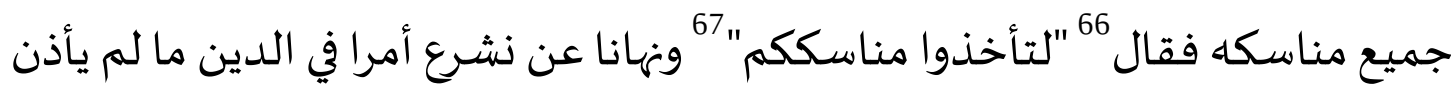

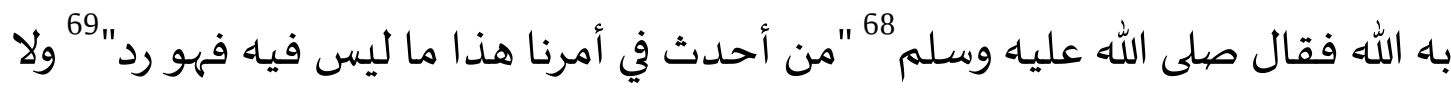

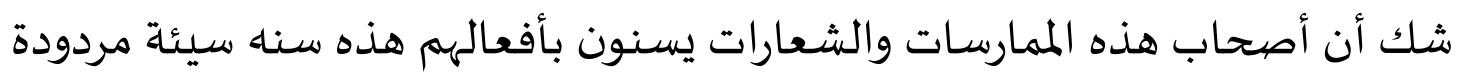
يحملون وزرها ووزر من عمل بها إلى يوم القيامة كما قال النبي صلى الله عليه وسلم 70

66 أخرجه مسلم في صحيحه، كتاب الحج، باب استحباب رمي جمرة العقبة يوم النحر راكبا، من حديث جابر رضي الله عنه،

${ }^{67}$ al-Ḥajjāj, Ṣaḥịh Muslim, p. 589.

عنها، رقم الحديث 68 أخرجه البخاري في صحيحه، في كتاب الصلح، باب إذا اصطلحوا على صلح جور فالصلح مردود، من حديث عائشة رضي الله

${ }^{69}$ al-Bukhārī, al-Jāmi’ al-Ṣaḥịh, vol. 2. p. 297.

70 أخرجه مسلم في صحيحه، كتاب الزكاة، باب الحث على الصدقة ولو بشق تمرة أو كلمة طيبة وأنها حجاب من النار، من

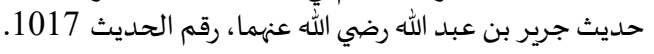


"من سن في الإسلام سنـة سيئة كان علياه وزرها ووزر من عمل بها من بعده من غير أن 71 من

\section{د. الخاتهة}

بناء على ما سبق يتضح لنا أن كل مظهر من مظاهر قومية وطائفية من أفعال وأقوال في شعيرة الحج "الأكبر والأصغر" بما فيه تفريق وتفكيك لوحدة المسلمين ليس مشروعا بل رفضيه الإسلام. وأن الحج هو مؤتمر حاشد للأمة الإسلامية أبطل الله فيـ فوارق الجنس واللون واللسان والوطن ليعلمنا أن شعيرة الحج لهي أكبر شـاهد على الأخوة الإسلامية في أسمى معانها وأنها فاقت أخوة النسب والقبيلة والوطن، فإذا أريد الاجتماع لها وقصد بها على معان أو شعارات أخرى غير الانتماء إلى الدين والانتساب إلى الملة كان الاجتماع باطلا منافيا للمقصود الذي من أجله شُرع.

\section{BIBLIOGRAPHY}

Abu Zayd, Wașfī' Āshūr. Ru'yah Maqāșidiyyah fī Aḥwāl al-'Așriyyah. 1 ed. Cairo: Dār al Maqāṣid li al-Ṭibā'ah wa al-Nasyr, 2017.

Affāni, Sayyid Husayn Al. al-Riyāẹ al-Na dirah fī Fa dạil al-Hajj wa al-'Umrah. 2 ed. Maktabah Mu'ādh bin Jabai, 1997.

Al-'Ayn̄̄, Badru al-Dīn Aḥmad Abū Muhammad Maḥmūd Bin Aḥmad. 'Umdah alQāri Sharḥ Șahi ḥ àl-Bukhārī. 1 ed. Beyrut: Dār al-Kutub al-'Ilmiyyah, 2001.

Al-Albānī, Nāṣir al-Dīn. Sạ̣̄ḥ̣ Sunan al-Albān̄̄. 1 ed. Riyāḍ: Maktabah Al Ma’ārif, 1998.

Al-Bayḍāwī, Nāșir al-Dīn. Tafsīr al-Bayḍāwī al-Musammā bi Anwār al-Tanzīl wa Asrār al-T̄a'wīl. 2 ed. Beyrut: Dār al-Ma'rifah, 2017.

Al-Bukhārī, Abū Abdillah Muḥammad bin Ismā’̄il. al-Jāmi’ al-Ṣaḥ̄ḥ. Cairo: al

${ }^{71}$ al-Hajajāj, Șaḥịh Muslim, P. 452. 
Maktabah al Salafiyyah, 1440.

Al-Ḥajjāj, Abū al-Ḥusayn Muslim bin. Șaḥị̣ Muslim. 2 ed. Riyāḍ: Dār al Ṭayyibah, 2006.

Al-Ḥamawī, Shīhābuddīn Abū Abdillah Ya'qūt. Mu’jam al-Buldān. Beyrut: Dār Șādir, 1977.

Al-Jașșāṣ, Abu Bakr Aḥmad bin 'Alī al-Rāzī. A hkkām al-Qurān. Beyrut: Dār al-Kutub al-'Ilmiyyah, 2012.

al-Jurjānī, 'Alī bin Muhammad bin 'Alī al-Zayn al-Sharīf. al-Ta'rīfāt. 1 ed. Beyrut: Dār al-Kutub al-'Ilmiyyah, 1883.

Al-Nadawī, Abū al-Hasan 'Alī al-Hasanī. al-Arkān al-Arba'ah (al-Ṣalāh, al-Zakāh, al-Ṣawm, al-Hajj) fi Daw $i$ al-Kitāb wa al-Sunnah Muqäranah ma'a alDiyānāt al-Ukhrā. Cairo: Dār al-Kutub al-'Ilmiyyah, 1387.

Al-Qurțūbī, Abū Abdillah Muhammad bin Ahmad bin Bi Bakr. al-Jāmi' li Ahkā̄m alQurān wa al-Mubayyin limā Tadammanahu min al-Sunnah wa Āȳ al-Furqān. 1 ed. Beyrut: Muassasah al-Risāiah, 2006.

Al-Raḥmūn̄̄, Muḥammad al-Sharīf. Manāsik al-Hajj wa al-'Umrah min al-Qurān wa al-Sunnah Dirāsah wa Taṭ̂ìq. Tūnis: Dār al-'Arabiyyah li al-Kitāb, n.d.

Al-Ṣābūn̄̄, Muhammad Alī. Qabas Min Nūr al-Qurān. 2 ed. Damaskus: Dār alQalam, 1988.

Al-Sa'ad, Khālid Khalīfah. Khuțab Shaykh al-Qaraḍāwī. Cairo: Maktabah Wahdah, n.d.

Al-Sajistān̄̄, Abū Dawd Sulaymān bin Ash 'as. Kitāb Sunan. 1 ed. Jeddah: Dār al Qiblah, 1998.

Al-Shadd̄̄, 'Ādil bin 'Alī. "Maqāṣid al-Hajj fī al-Qurān al-Karīm.” Majallah Jāmi'ah Umm al-Qurrā li 'Ulūm al-Sharì'ah wa al-Dirāsah al-Islāmiyyah 44 (1429).

Al-Shuraym, Su'ūd bin Ibrāhīm. al-Minhāj li al-Mu'tamir wa al-Ḥājj. 1 ed. Riyāḍ: Dār al-Wațan, 1994.

Al-Subkī, Abu al-Hasan Taqiyyuddīn 'Alī bin Abd al-Kāfī. Fatāwā al-Subkī. Beyrut: Dār al-Ma'rifah, n.d.

Al-Tahānawī, Zāfir Ahmmad al-Uthmānī. I'lān al-Sunan. 3 ed. Pakistan: Idārah alQurān wa al-Ulum Al-Islamiyah, 1415.

Al-Tïmidhī, Muhạmmad bin ' İsa. al-Jāmi' al-Tirmidhī. 1 ed. Riyāḍ: Maktabah Al Ma'ārif, n.d.

Al-Zahrānī, Nāṣir. Ihāj al-Hajj. 3 ed. Egypt: Al Maktabah Al Waqfiyyah, 1995.

Andī, Șāliḥ Rūbin. Rawā'i al-Hikam min Hadìth al-'Arab wa al-A'jām. Dubay: alManhal, 2013.

Baharuddin, A. Zamakhsyari. "Pengawasan Terhadap Acara Televisi Dalam Perspektif Fiqh Islami dan UU No. 32 Tahun 2002 Tentang Penyiaran Indonesia." Syarif Hidayatullah State Islamic University Jakarta, 2017.

Bayhāqi, Abu Bakr Aḥmad bin al-Ḥusayn al. al-Sunan al-Kubrā. 3 ed. Beyrut: Dār al- 
Kutub al-'Ilmiyyah, 2003.

Ibn Mājah, Muhammad bin Yazīd al-Qazwīnī. Sunan. Cairo: Dār Ihyā al-Kutub al'Arabiyyah, n.d.

Ibn Kathīr, Abū al-Fidā Ismā'īl. Tafsīr al-Qurān al-'Aẓim. 1 ed. Beyrut: Dār Ibn Hazm, 2000.

Khaț̣̂̄b, Amīn Maḥmūd. ā1 ed. Beyrut: Muassasah al-Tārīkh al-'Arabī, 1974.

La'zūzī, Mușțafā. Thaqāfah al-Hajj 'Ibādah wa Akhlāk, Fannun wa Indibāț. 1 ed. Beyrūt: Dār al-Kutub al-'Ilmiyyah, 2006.

"Penjelasan Banser Soal Yaa Lal Wathan di Mekkah: Murni Spontanitas." MusliModerat, 2018. http://www.muslimoderat.net/2018/02/penjelasanbanser-soal-yaa-lal-wathan.html.

Pirman. “Tegas! Begini Cara Arab Saudi 'Semprot' Penyanyi Ya Lal Wathon Saat Sa'i." Tarbawiyah Net, 2018. https://www.tarbawia.net/2018/02/tegas-beginicara-arab-saudi-semprot.html.

Quțub, Sayyid. F̄̄ Zilāl al-Qurān. Beyrut: Dār al-Shurūq, 2003.

Salhab, Hasan. al-Shaykh Mahmūd Shaltūt Qirāah fī Tajrībah al-Ișlāh wa al-Wiḥdah al-Islāmiyyah. 1 ed. Beyrut: Markaz al-Ḥad\}ārah lī Tanmiyah al-Fikr alIslāmī, 2008.

Shaltūt, Maḥmūd. Min Tawj̄̄hāt al-Islām. 8 ed. Beyrut: Dār al-Shurūq, 2004.

Sharī'atī, 'Alī. al-Farīụah al-Khamsah. 2 ed. Giza: Dār al-Asmā, 1992.

Shawqī, Ibrāhīm Anwār. "Istikhdām al-Shi'ārāt al-Siyāsiyyah fī al-Ḥajj." Dār al-Iftā al-Mișriyyah, 2013. alifta.org/ar/ViewFatwa.aspx?ID=13973\&LangID=1\&MuftiType=. http://www.dar-

Ṭīrah, Maḥmūd Ibrāhīm. “al-Ḥajj.” Majallah al-Islām 46 (1354): 2181. 


\section{Guidelines}

\section{Submission of Article}

urnal Adabiyah welcomes the articles submission with the main themes on Humanities and Islamic Studies with the emphasis on interdisciplinary and intertextuality approach. Adabiyah is thematicly published twice in a year. ie the theme of the humanities in June and the Islamic Study in December.

Themes related to Islamic Studies are textual studies, scriptural traditions, Islamic law, and theology; and those related to Humanities are language, literature, history, and culture. This scholarly journal Guarantees that the editor decision based on the peer review results will not exceed 30 days from the paper submission date.

Authors are invited to read our archives; to find the relevant topics for the journal, and to submit complete unpublished scientific researches, which are not under review in any other conferences or academic journal.

\section{PUBLICATION ETHIC}

Publication Ethic and Malpractice Statement

Jurnal Adabiyah is a peer-reviewed journal, published twice a year by the Faculty of Adab and Humaniora, Alauddin State Islamic University of Makassar Indonesia. It is available online as open access sources as well as in print. This statement clarifies ethical behaviour of all parties involved in the act of publishing an article in this journal, including the author, the editor-in-chief, the Editorial Board, the reviewers, and the publisher. This statement is based on COPE's Best Practice Guidelines for Journal Editors.

Ethical Guideline for Journal Publication

The publication of an article in Jurnal Adabiyah, is an essential building block in the development of a coherent and respected network of knowledge. It is a direct reflection of the quality of the work of the authors and the institutions that support them. Peer-reviewed articles support and embody the scientific methods. It is therefore important to agree upon standards of expected ethical behavior for all parties involved in the act of publishing: the author, the editor, the reviewer, the publisher, and the society. As the publisher of Jurnal Adabiyah, the Faculty of Adab and Humaniora takes its duties of guardianship over all stages of publishing seriously and it recognizes its ethical and other responsibilities. The Faculty of Adab and Humaniora committed to ensuring that advertising, reprint or other commercial revenue has no impact or influence on editorial decisions.

\section{Publication Decisions}

The editors of Jurnal Adabiyah is responsible for deciding which articles submitted to the journal should be published. The validation of the work in question and its importance to researchers and readers must always drive such decisions. The editors may be guided by the policies of the journal's editorial board and constrained by such legal requirements as shall then be in force regarding libel, copyright infringement, and plagiarism. The editors may confer with other editors or reviewers in making their decisions.

\section{Plagiarism Screening}

It is basically author's duty to only submit a manuscript that is free from plagiarism and academically malpractices. The editor, however, will check all submitted papers through Turnitin.

\section{Fair Play}

An editor at any time evaluates manuscripts for their intellectual content without regard to race, gender, sexual orientation, religious belief, ethnic origin, citizenship, or political philosophy of the authors. 


\section{Confidentiality}

The editors and any editorial staff must not disclose any information about a submitted manuscript to anyone other than the corresponding author, reviewers, potential reviewers, other editorial advisers, and the publisher, as appropriate.

\section{Disclosure and Conflicts of Interest}

Unpublished materials disclosed in a submitted manuscript must not be used in editors' own research without the express written consent of the author.

\section{DUTIES OF AUTHORS}

\section{Reporting Standards}

Authors of reports of original research should present an accurate account of the work performed as well as an objective discussion of its significance. Underlying data should be represented accurately in the paper. A paper should contain sufficient detail and references to permit others to replicate the work. Fraudulent or knowingly inaccurate statements constitute unethical behaviour and are unacceptable.

\section{Originality and Plagiarism}

The authors should ensure that they have written entirely original works, and if the authors have used the work and/or words of others that this has been appropriately cited or quoted.

\section{Multiple, Redundant, or Concurrent Publication}

An author should not in general publish manuscripts describing essentially the same research in more than one journal or primary publication. Submitting the same manuscript to more than one journal concurrently constitutes unethical publishing behaviour and is unacceptable.

\section{Acknowledgement of Sources}

Proper acknowledgment of the work of others must always be given. Authors should cite publications that have been influential in determining the nature of the reported work.

\section{Authorship of the Paper}

Authorship should be limited to those who have made a significant contribution to the conception, design, execution, or interpretation of the reported research. All those who have made significant contributions should be listed as co-authors. Where there are others who have participated in certain substantive aspects of the research project, they should be acknowledged or listed as contributors. The corresponding author should ensure that all appropriate co-authors and no inappropriate co-authors are included on the paper, and that all co-authors have seen and approved the final version of the paper and have agreed to its submission for publication.

\section{Disclosure and Conflicts of Interest}

All authors should disclose in their manuscript any financial or other substantive conflict of interest that might be construed to influence the results or interpretation of their manuscript. All sources of financial support for the project should be disclosed.

\section{Fundamental errors in Published Works}

When an author discovers a significant error or inaccuracy in his/her own published work, it is the author's obligation to promptly notify the journal editor or publisher and cooperate with the editor to retract or correct the paper.

\section{PLAGIARISMIE}

It is basically author's duty to only submit a manuscript that is free from plagiarism and academically malpractices. The editor, however, will check all submitted papers through Turnitin. 


\section{AUTHOR GUIDELINES}

\section{Guidelines for online submission:}

1. Author should first register as Author to the website of Jurnal Adabiyah. Click the menu "register" to register as an author.

2. Once after the author is registered, please login to the website of Jurnal Adabiyah and submit the article through online submission (with the stat us of active submissions).

3. The article should follow the standard template of Jurnal Adabiyah provided in the website.

4. The citation and bibliography should follow the Turabian citation style.

5. Author is restricted not to send his/her article to another journal before having confirmation from the editorial team (approximately 4 weeks right after the article submitted).

6. Author should follow editorial decisions and recommendations related to the article completion. All reviews and assessements will be informed through online submission.

Article submitted to Jurnal Adabiyah editorial board must follow these guidelines:

1. Article should be based on the scientific research in the field humanities and Islamic studies;

2. Article must be an original work and has not been previously published;

3. Article should be written in Arabic or English languages;

4. Article must be typed in one-half spaced on A4-paper size;

5. Article's length is about $6,000-10,000$ words;

6. All submission must include a 150-250 word abstract;

7. Abstract should be written in 3 languages; Arabic, English, and Bahasa;

8. Full name(s) of the author(s) must be stated, along with his/her/their institution and complete address;

9. All submission should be in OpenOffice, Microsoft Word, RTF, or WordPerfect document file format;

10. Bibliographical reference must be noted in footnote and bibliography according to Jurnal Adabiyah style. In addition, it is suggested for author(s) to use reference manager tools such

\section{as MENDELEY or 7 otero}

When a source is cited for the first time, full information is provided: full name(s) of author(s), title of the source in italic, place of publication, publishing company, date of publication, and the precise page that is cited. For the following citations of the same source, list the author's last name, two or three words of the title, and the specific page number(s). The word ibid., op.cit., and loc.cit. are may not be used any more.

\section{Example in footnotes:}

${ }^{1}$ Mircea Eliade (ed.), The Encyclopedia of Religion, vol. 8 (New York: Simon and Schuster, 1995), h. 18.

${ }^{2}$ Norman Daniel, Islam and the West (Oxford: One World Publications, 1991), h. 190.

${ }^{3}$ Syeikh Ja'far Subhāni, Mafăhim Al-Qur'ān (Beirut: Mu'assasah Al-Tarīkh Al-'Arabī, 2010)., Juz 5, h. 231. 
${ }^{4}$ Syeikh Ja'far Subhānī, Mafāhim Al-Qur'ān, h. 8-9.

\section{Example in bibliography:}

Subhānī, Syeikh Ja'far. Mafăhim Al-Qur'ān. Beirut: Mu'assasah Al-Tarīkh Al-’Arabī, 2010.

Eliade, Mircea (ed.). The Encyclopedia of Religion, vol. 8. New York: Simon and Schuster, 1995.

Daniel, Norman. Islam and the West. Oxford: One World Publications, 1991.

Shihab, Muhammad Quraish. Sunnah-Syiah Bergandengan Tangan: Mungkinkah? Kajian Atas Konsep Ajaran Dan Pemikiran. Cet. III. Jakarta: Lentera Hati, 2007.

\section{Detail informations of the footnotes:}

1. Holy book

Al-Qur'ân, Al-Baqarah/2: 185.

Perjanjian Baru, Mrk. 2: 18.

2. Qur'anic translation

${ }^{1}$ Departemen Agama RI, al-Qur'an dan Terjemahannya (Jakarta: Darus Sunnah, 2005), h. 55.

3. Book

${ }^{1}$ Muḥammad 'Ajjaj al-Khațib, Ușl al-Hadith: 'Ulumuh wa Mușțalaḥ uh (Beirut: Dâr al-Fikr, 1989), h. 57.

4. Translation Books

${ }^{1}$ Toshihiko Izutsu, Relasi Tuhan dan Manusia: Pendekatan Semantik terhadap al-Qur'an, terj. Agus Fahri Husein dkk (Yogyakarta: Tiara Wacana, 2003), h. 14.

5. Voluminous book

${ }^{1}$ Muḥammad al-Ṭâhir b. 'Ashur, al-Tahrīir wa al-Tanwīr, Vol. 25 (Tunisia: Dâr al-Suhûn, 2009), h. 76.

${ }^{1}$ Muḥammad b. Ismā‘īl al-Bukharī, al-Jami‘ al-Ṣaḥịh, Vol. 2 (Beirut: Dar al-Kutub al-‘Ilmı́yah, 1999), h. 77.

6. Article in book

${ }^{1}$ Sahiron Syamsuddin, "Metode Intratekstualitas Muhammad Shahrur dalam Penafsiran al-Qur'an" dalam Abdul Mustaqim dan Sahiron Syamsuddin (eds.), Studi al-Qur'an Kontemporer: Wacana Baru Berbagai Metodologi Tafsir (Yogyakarta: Tiara Wacana, 2002), h. 139.

7. Article in encyclopaedia

${ }^{1}$ M. Th. Houtsma, "Kufr" dalam A. J. Wensinck, at al. (ed.), First Encyclopaedia of Islam, Vol. 6 (Leiden: E.J. Brill, 1987), h. 244.

8. Article in journal

${ }^{1}$ Muhammad Adlin Sila, "The Festivity of Maulid Nabi in Cikoang, South Sulawesi: Between Remembering and Exaggerating the Spirit of Prophet", Studia Islamika 8, no. 3 (2001): h. 9.

9. Article in mass media

${ }^{1}$ Masdar F. Mas'udi, "Hubungan Agama dan Negara”, Kompas, 7 Agustus 2002. 
10. Article in Internet

${ }^{1}$ Muhammad Shahrūr, "Reading the Religious Teks: a New Approach" dalam http://www.shahrour.org/25 Februari 2010/diakses 5 Juni 2010.

11. Thesis or dissertation

${ }^{1}$ Syahruddin Usman, "KinerjaGuru Penddikan Agama Islam pada SMAN dan SMKN Kota Makassar”, Disertasi (Makassar: PPs UIN Alauddin, 2010), h. 200.

\section{COPYRIGHT NOTICE}

Authors who publish with this journal agree to the following terms:

1) Authors retain copyright and grant the journal right of first publication with the work simultaneously licensed under a Creative Commons Attribution License that allows others to share the work with an acknowledgement of the work's authorship and initial publication in this journal.

2) Authors are able to enter into separate, additional contractual arrangements for the non-exclusive distribution of the journal's published version of the work (e.g., post it to an institutional repository or publish it in a book), with an acknowledgement of its initial publication in this journal.

3)Authors are permitted and encouraged to post their work online (e.g., in institutional repositories or on their website) prior to and during the submission process, as it can lead to productive exchanges, as well as earlier and greater citation of published work (See The Effect of Open Access). 